\title{
等価線形化手法による一質点弾塑性構造の最大応答予測法
}

\section{PEAK RESPONSE PREDICTION RULE FOR A SDOF ELASTO-PLASTIC SYSTEM BASED ON EQUIVALENT LINEARIZATION TECHNIQUE}

\author{
笠井和彦*, 伊藤 浩 資**, 渡辺 厚*** \\ Kazuhiko KASAI, Hiroshi ITO and Atsushi WATANABE
}

\begin{abstract}
This paper proposes a simplified method to predict the peak displacement and base shear of a single-degree-of-freedom nonlinear structure subjected to earthquakes. The method considers bilinear hysteresis, and it can express the peak responses as functions of the dynamic property of the structure and the elastic response spectrum. It is based on equivalent linearization as well as spectrum modification and reduction, reflecting increase in equivalent vibration period and damping ratio. The method is validated through numerous time history analyses over a wide range of elastic vibration period, yield strength, post-yield stiffness, ductility, and earthquake type.
\end{abstract}

Keywords : equivalent linearization, single-degree-of-freedom (SDOF) elasto-plastic structure, damping effect factor, response spectrum, peak displacement, peak force

等価線形化, 一質点弾塑性構造, 応答低減率, 応答スペクトル, 最大変位, 最大力

1. はじめに

\section{1 背景}

地震時における構造物の非線形応答を予測する代表的な手法と して、コンピューターによる時刻歷解析があるが、その結果は、あ る入力地震動に対する特解であり、そこから構造物の耐震性能を包 括的に把握することは難しい ${ }^{1), 2) 。 ~}$

このため、地震波のスペクトル特性に基づき、構造の動的特性と 地震波の特性を関連づけながら、最大応答を簡易に予測するような

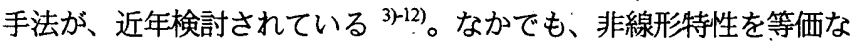
剛性と減衰をもつ線形モデルに近似するという、いわゆる等価線形 化に基づくものは、簡易で有用な手法と言うことができる。

この手法の基本的な算定プロセスは、以下のごとくである。

1) 仮定した最大変形から、構造物の剛性低下および履歷エネルギー 吸収を表す等価周期と等価减衰定数の評価を行う。

2) この結果を用い、線形時刻歷解析あるいは線形応答スペクトルか

ら最大変形を求める。これを新たな仮定值として 1)に戻る。

3) 最大変形の値の収れん後、相当する最大力などを求める。

既往手法の等価周期・減衰定数の求め方は様々である ${ }^{35-8), ~ 10-21) 。 ~}$ また、時刻歷解析よりも、応答スペクトルの方が構造特性と応答の 関連を理解しやすいが、過程 2)で減衰定数に即しスペクトル曲線を. 作成する作業が煩雑になる。そこで、初期減衰での線形応答スペク トル曲線を低減したものを代用し、その作業を省略する方法が、約 30 年前に柴田 ${ }^{6), 7)}$ によって示唆され、さらに近年においてその展開
が図られている4), 55, 10)-12)。これによれば、任意の減衰での応答を迅 速に評価でき、よって様々な入力レベルでの耐震性能の把握が効率 的になる。また、後述するように収れん計算の簡素化や省略にも媻 がることになる。

\section{2 本論文の目的之構成}

以上の観点から、本論文の目的は、等価線形化および減衰による 線形応答スペクトルの低減からなる応答予測法を提案するとともに、 同系の他手法と比べながら、その精度を検証することである。バイ リニア履歴特性をもつ一質点弾塑性構造を対象とする。

弾塑性構造は、地震入力ではサイクル毎に異なる履歴振幅を示す ため、一定の岡性や減衰定数をもつ線形システムで模擬するには、 宿命的に愦差が伴う。また、スペクトル曲線の平滑さや低減の度合 いが、周期や減衰に必ずしも規則的に依存しないため、スペクトル 值の低減の過程で、誤差が生じることは明らかである。本手法では、 これらの誤差を抑えるための配慮がなされているが、従来の等価線 形化手法と同様、経験的な精度調整に基づく面もある。

したがって、手法の精度限界や適用範囲に関し、多くの検証例が 必要と考え、30 波を超える地震波と、様々な初期周期、二次剛性比、 降伏力、塑性率などの組み合わせからなる多数のケースにつき、本 手法・他手法の予測值と、非線型時刻歷解析の結果を比較する。

2 章では、減衰による線形応答スペクトル低減の予測式を提案し、 その精度の妥当性を示すとともに、他式との比較を行う。3 章では、 本応答予測手法の提案を行い、その理論について述べる。さらに、
$*$ 東京工業大学建築物理研究センター 教授・Ph. D.

** 東京工業大学人間環境システム専攻 大学院生

****新日本製鉄(株)
Prof., Str'l Eng. Research Center, Tokyo Institute of Technology, Ph. D. Grad. Student, Dept. of Built Environment, Tokyo Institute of Technology Nippon Steel Corporation 
本手法・他手法について、その概念や算定法の相違点を示し、多く の時刻歴解析に基づき、予測精度の検証を行う。4 章では、設計時 によく考慮される擬似加速度、擬似速度、変位応答スペクトルが一 定の場合について、弾塑性構造の応答傾向を示す簡潔な予測式が本 手法から求まることを示し、その内容についても述べる。

\section{2. 減衰による志答スペクトルの低減効果}

\section{1 応答低隇率 $D_{h}$ の予測式}

任意の減衰定数における線形応答スペクトル值の近似予測法と して、初期減衰でのスペクトル值と減衰による応答低減率 $D_{h}$ の積を 用いる方法がある。 $D_{h}$ の既往予測式について精度の検証例が少なか ったため、本章では多数の地震波を用いて、詳細な検討を行う。

ところで、スペクトル量として変位・擬似速度・擬似加速応答ス ペクトル $S_{d}, S_{p v}, S_{p a}$ および速度・加速度応答スペクトル $S_{w}, S_{a}$ がある か、既往の低減率 $D_{h}$ では、どの応答を対象としたのか曖昧な場合も あり、さらにそれを異なる応答の予測に用いた例も見られる。

そこで本論では、固有円振動数 $\omega$ を介し $S_{d}=S_{p v} / \omega=S_{p a} / \omega^{2}$ の対応 関係がある変位・擬似速度・擬似加速度応答スペクトルについて、 共通な低減率 $D_{h}$ を定義し、速度応答スペクトル $S_{w}$ 加速度応答スペ クトル $S_{a}$ それそれの低減率とは明確に区別する (付録 1)。

また、特に $S_{d}, S_{p v}, S_{p a}$ 共通の低減率は、 $S_{w}, S_{a}$ それそれの低減率と 異なり、周期 0.2 3.0 秒程度では周期にあまり依存しないという重 要な傾向がある (付録 1)。よって、周期に依存しない表現である既 往の予測式に着目し、その適用性を検討する。式(1) (4)は、それそ れ、秋山 ${ }^{3)} 、$ Hanson"、笠井 ${ }^{4)}$,22)、建築研究所 (以下、建研 ${ }^{5), 8)}$ によ るものであり、これらを $D_{h}$ (予測)と呼ぶ。

$$
\begin{aligned}
& D_{h}=\left(1+3 h_{0}+1.2 \sqrt{h_{0}}\right) /\left(1+3 h_{e q}+1.2 \sqrt{h_{e q}}\right) \\
& D_{h}=\sqrt{\left[\left(1-e^{-18 h_{e q}}\right) h_{0}\right] /\left[\left(1-e^{-18 h_{0}}\right) h_{e q}\right]} \\
& D_{h}=\sqrt{\left(1+25 h_{0}\right) /\left(1+25 h_{e q}\right)} \\
& D_{h}=\left(1+10 h_{0}\right) /\left(1+10 h_{e q}\right) \\
& \text { ただし、 } D_{h} \geq 0.32\left(h_{0}=0.02\right), D_{h} \geq 0.40 \quad\left(h_{0}=0.05\right)
\end{aligned}
$$

ここで、 $h_{0}, h_{e q}=$ 初期減衰定数と等価減衰定数である。図 1 と表 1 に、 $h_{0}=0.02,0.05$ の場合それぞれにつき、 $h_{e q}=h_{0} \sim 0.4$ における各式 の $D_{h}$ (予測) 值を示す。建研式は、他式に比べ応答低減の度合いが 大きく、 $h_{e q} \geqq 0.275$ の時に下限值をもつことが異なる。

なお、付録 1 で周期・地震継続時間の影響を応答種別ごとに述べ、 付録 2 に非常に広い周期領域での応答低減率の予測法も示す。

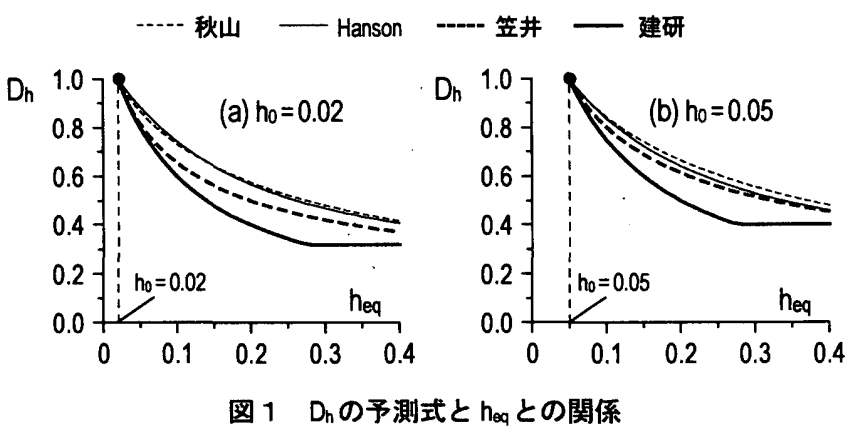

表 $1 \quad D_{h}$ の予測式と $h_{\mathrm{eq}}$ との関係 $\quad\left(\right.$ 上 : $h_{0}=0.02$, 下 : $\left.h_{0}=0.05\right)$

\begin{tabular}{|c|c|c|c|c|c|c|}
\hline & \multicolumn{7}{|c|}{ 等価减衰定数 $\mathrm{h}_{\mathrm{eq}}$} \\
\cline { 2 - 7 } & 0.02 & 0.05 & 0.1 & 0.2 & 0.3 & 0.4 \\
\hline 秋山 & 1.000 & 0.867 & 0.732 & 0.576 & 0.481 & 0.416 \\
\hline Hanson & 1.000 & 0.886 & 0.743 & 0.567 & 0.469 & 0.407 \\
\hline 笠开 & 1.000 & 0.816 & 0.655 & 0.500 & 0.420 & 0.369 \\
\hline 建研 & 1.000 & 0.800 & 0.600 & 0.400 & 0.320 & 0.320 \\
\hline
\end{tabular}

\begin{tabular}{|c|c|c|c|c|c|c|}
\hline & \multicolumn{7}{|c|}{ 等価减衰定数 $\mathrm{h}_{\text {eq }}$} \\
\cline { 2 - 7 } & 0.02 & 0.05 & 0.1 & 0.2 & 0.3 & 0.4 \\
\hline 秋山 & 1.153 & 1.000 & 0.845 & 0.664 & 0.555 & 0.479 \\
\hline Hanson & 1.129 & 1.000 & 0.839 & 0.640 & 0.529 & 0.459 \\
\hline 䇠井 & 1.225 & 1.000 & 0.802 & 0.612 & 0.514 & 0.452 \\
\hline 建研 & 1.250 & 1.000 & 0.750 & 0.500 & 0.400 & 0.400 \\
\hline
\end{tabular}

\section{2 実際の応答低減率}

表 2 は、本論で対象とする 33 種地震波 (2 種模擬地震波を含む) の最大加速度、入力時間、そして Bolt ${ }^{23)}$, 24)および Trifunac \& Brady ${ }^{24)}$, ${ }^{25)}$ の手法 (付録 1) により継続時間を評価した值を示している。各地 震波における実際の応答低減率 $D_{h}$ (解析)を、以下の手順で求めた。

各地震波に対し、9 種の減衰定数 $h_{e q}=0.02,0.05,0.10,0.15,0.20$, $0.25,0.30,0.35,0.40$ を考え、計 297 の応答スペクトル曲線を作成し た。 $D_{h}($ 解析 $)$ は、変位応答スペクトル值 $S_{d}\left(h_{e q}\right)$ と $S_{d}\left(h_{0}\right)$ の比を、周期 $0.2 \sim 3.0$ 秒において 0.01 秒刻みで 281 点 $(=n)$ 算出し、さらにそれら を平均した值である。

$$
D_{h}(\text { 解析 })=\frac{1}{n} \sum_{i=1}^{n}\left[\frac{S_{d}\left(h_{e q}, T_{i}\right)}{S_{d}\left(h_{0}, T_{i}\right)}\right]
$$

\begin{tabular}{|c|c|c|c|c|c|c|}
\hline \multirow[b]{2}{*}{ No. } & \multirow{2}{*}{\multicolumn{2}{|c|}{ 地震波名 }} & \multirow{2}{*}{$\begin{array}{c}\text { 最大加速度 } \\
\left(\mathrm{cm} / \mathrm{sec}^{2}\right)\end{array}$} & \multirow{2}{*}{$\begin{array}{c}\text { 入力時間 } \\
(\mathrm{sec})\end{array}$} & \multicolumn{2}{|c|}{ 継続時間評価値 (sec) } \\
\hline & & & & & Bolt & $\begin{array}{l}\text { Trifunac } \\
\& \text { Brady }\end{array}$ \\
\hline 1 & \multirow{2}{*}{\begin{tabular}{|c|} 
Imperial Valley \\
1940 \\
\end{tabular}} & El Centro NS & 341.70 & 53.74 & 29.30 & 24.40 \\
\hline 2 & & El Centro EW & 210.10 & 53.46 & 26.58 & 24.52 \\
\hline 3 & \multirow{2}{*}{$\begin{array}{c}\text { Kern Country } \\
1952\end{array}$} & Taft N021E & 152.70 & 54.36 & 19.58 & 30.52 \\
\hline 4 & & Taft N111E & 175.90 & 54.38 & 15.56 & 28.84 \\
\hline 5 & \multirow{2}{*}{$\begin{array}{c}\text { 十勝沖 } \\
1968\end{array}$} & 八戸 NS & 272.09 & 71.99 & 53.04 & 41.28 \\
\hline 6 & & 八戸 $\mathrm{EW}$ & 199.89 & 71.99 & 47.37 & 36.77 \\
\hline 7 & \multirow{6}{*}{$\begin{array}{c}\text { 兵庫県南部 } \\
1995\end{array}$} & JMA神戸NS & 820.56 & 30.06 & 21.88 & 8.10 \\
\hline 8 & & JMA神户 EW & 619.20 & 30.06 & 17.66 & 9.50 \\
\hline 9 & & 大阪ガス幕合 N240E & 686.50 & 81.69 & 15.10 & 7.04 \\
\hline 10 & & 大阪ガス幕合 N330E & 802.00 & 81.69 & 14.30 & 6.75 \\
\hline 11 & & JR/鷹取駅 NS & 605.55 & 40.95 & 31.94 & 11.33 \\
\hline 12 & & JR鷹取駅 EW & 656.98 & 40.95 & 19.86 & 9.93 \\
\hline 13 & \multirow{2}{*}{$\begin{array}{c}\text { 宮城県神 } \\
1978 \\
\end{array}$} & 東北大学 NS & 257.98 & 40.98 & 31.54 & 19.50 \\
\hline 14 & & 東北大学 EW & 203.01 & 40.98 & 38.00 & 22.38 \\
\hline 15 & \multirow{2}{*}{$\begin{array}{l}\text { 釧路神 } \\
1993\end{array}$} & JMA釧路 N063E & 692.81 & 157.40 & 57.75 & 18.89 \\
\hline 16 & & JMA鈵路 N153E & 576.01 & 157.40 & 48.93 & 21.66 \\
\hline 17 & \multirow{2}{*}{$\begin{array}{l}\text { Iran } \\
1978 \\
\end{array}$} & Tabas N074E & 862.85 & 49.98 & 44.60 & 18.40 \\
\hline 18 & & Tabas N344E & 919.02 & 49.98 & 44.82 & 18.06 \\
\hline 19 & \multirow{4}{*}{$\begin{array}{c}\text { Northridge } \\
1994\end{array}$} & Newhall NS & 578.19 & 59.98 & 15.70 & 5.50 \\
\hline 20 & & Newhall EW & 571.62 & 59.98 & 15.66 & 5.90 \\
\hline 21 & & Sylmar NS & 826.76 & 59.98 & 12.74 & 5.32 \\
\hline 22 & & Sylmar EW & 592.64 & 59.98 & 14.92 & 7.06 \\
\hline 23 & \multirow{6}{*}{$\begin{array}{c}\text { Chichi } \\
\text { (Taiwan) } \\
1999\end{array}$} & TCU065 NS & 563.27 & 160.00 & 42.83 & 28.90 \\
\hline 24 & & TCU065 EW & 774.30 & 160.05 & 43.85 & 29.17 \\
\hline 25 & & TCU068 NS & 361.94 & 150.00 & 24.99 & 13.30 \\
\hline 26 & & TCU068 EW & 501.43 & 150.00 & 26.90 & 12.54 \\
\hline 27 & & TCU074 NS & 368.34 & 160.00 & 70.38 & 21.36 \\
\hline \begin{tabular}{|l|}
28 \\
\end{tabular} & & TCU074 EW & 585.88 & 160.00 & 69.98 & 12.67 \\
\hline 29 & \multirow{3}{*}{$\begin{array}{c}\text { Kocaeli } \\
\text { (Turkey) } \\
1999\end{array}$} & Ypt NS & 322.20 & 135.81 & 34.99 & 31.84 \\
\hline 30 & & Ypt EW & 230.22 & 135.81 & 36.78 & 33.19 \\
\hline 31 & & Sakarya & 407.04 & 388.80 & 243.08 & 44.32 \\
\hline 32 & \multirow[t]{2}{*}{ 模䶶地震波 } & BCJ-L1 & 207.33 & 60.00 & 45.32 & 33.66 \\
\hline 33 & & BCJ-L2 & 355.66 & 120.00 & 106.97 & 65.28 \\
\hline
\end{tabular}

各周期での $S_{d}(0.05) / S_{d}(0.02), S_{d}(0.30) / S_{d}(0.02)$ の值、および式(5)に よる $D_{h}$ (解析)值を El Centro NS 波を例として、図 2 に示す。

\section{表 2 入力地震波一覧 （計 33 波）}




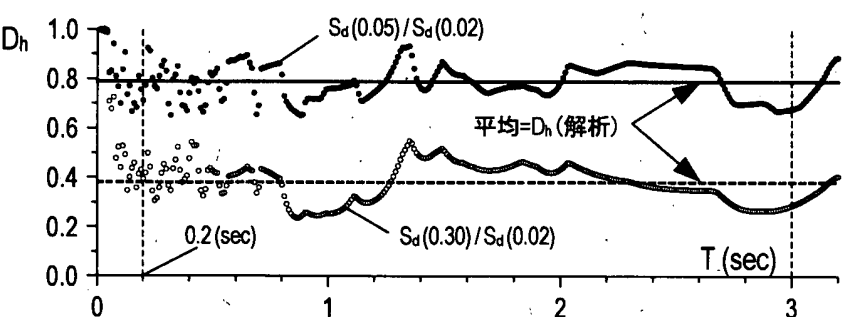

図 2 各周期 $\mathrm{T}$ における応答低隇率 $\quad(T=0.2$ 秒 3.0 秒の 281 点）

\section{3 予測式と解析值との比較}

上記 $D_{h}\left(\right.$ 予測)と $D_{h}$ (解析)の比較により、予測式の精度検討を行う。 紙幅の都合上、図 3 に 33 波のうち 12 波、 $h_{0}=0.02$ の場合について、 様々な $h_{e q}$ での $D_{h}$ (予測) $/ D_{h}$ (解析)の值を示す。各予測式の精度傾向 は、地震波によっであり変化しないことが、図3から理解できる。

さらに、全 33 波 $(=n)$ について、 $D_{h}($ 予測 $) / D_{h}$ (解析)の平均値 $A$ と 平均誤差値 $R$ を以下のように求める。

$$
\begin{aligned}
& A=\frac{1}{n} \sum_{i=1}^{n}\left[D_{h}(\text { 予測 }) / D_{h}(\text { 解析 })\right] \\
& R=\sqrt{\left.\frac{1}{n} \sum_{i=1}^{n}\left[D_{h}(\text { 予測 })-D_{h} \text { (解析 }\right)\right]^{2}}
\end{aligned}
$$

この結果を図 4, 図 5 に示す。秋山式と Hanson 式は、平均して応答 低減を安全側に、建研式では逆に危除側に評価している。建研式は、 特に $h_{e q}=0.20 \sim 0.30$ でこの傾向が強く、平均值 $0.7 \sim 0.8$ となってい る。また笠井式は、減衰定数によらず一貫して平均值がほほ 1.0 、平 均誤差值 0.05 以下と、非常に安定した精度を示している (図 5)。

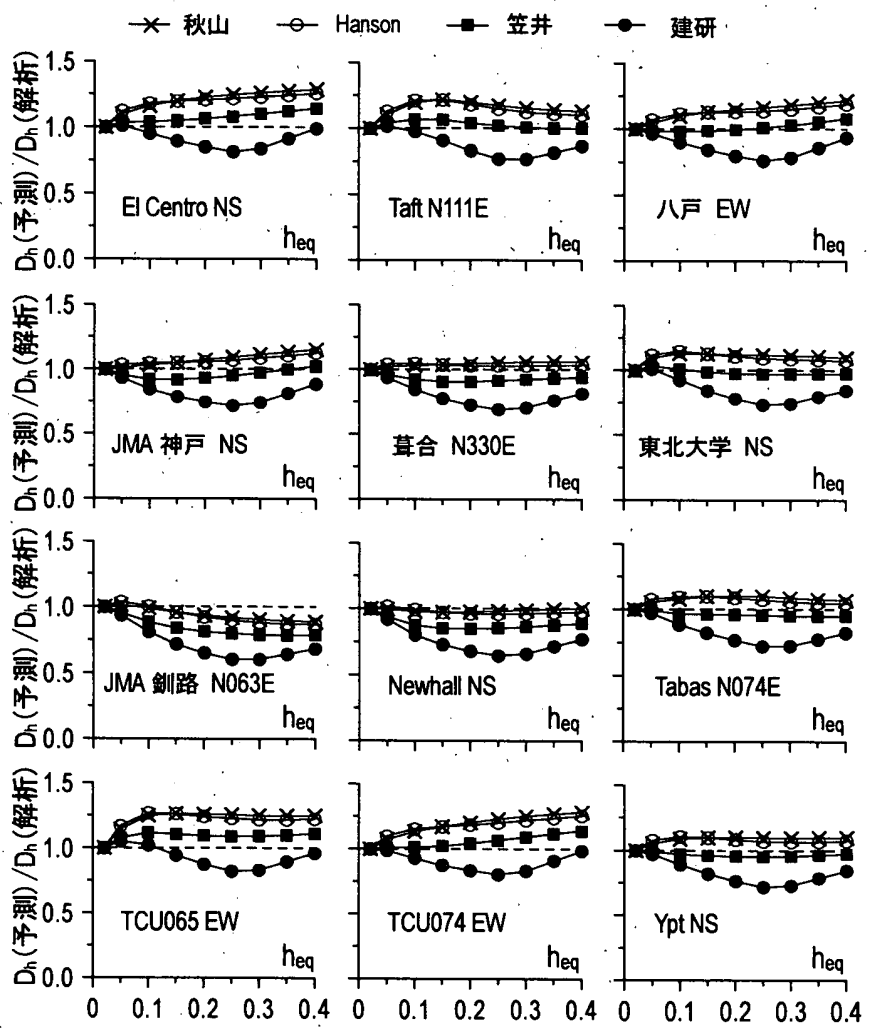

図3 予測式と解析值との比較例 ( $h_{0}=0.02,12$ 波の場合)
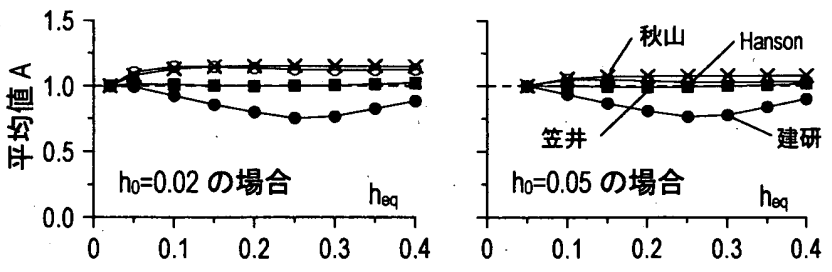

図 4 予測式と解析値との比較 (33 波の平均値)
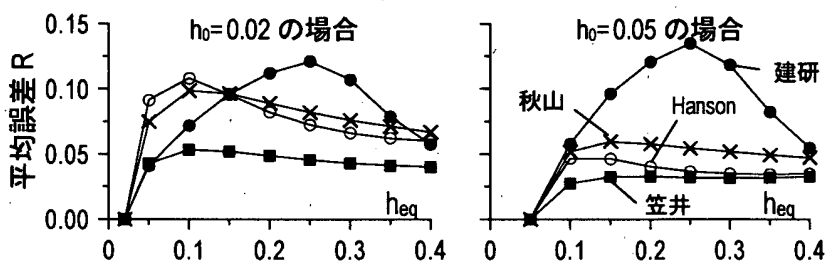

图 5 予測式と解析值との比較 (33 波の平均誤差)

\section{4 模擬地震波に関する注釈}

図 6 に各減衰での模擬地震波 2 波 (日本建築センタ一波 BCJ-L1, BCJ-L2) の低減率(式(5)) と 31 実地震波それそれの低减率(式(5))の 平均と標準偏差を示す。模擬地震波 2 波とも実地震波に比べ、減衰 による低減効果が著しい。よって、これらの模擬地震波での時刻歴 解析は、建物の安全性を過大評価する恐れがあり、他の模擬地震波 を作成·使用する場合でも、この点に留意する必要があると言える。

なお、上記傾向を実地震波に最も合った笠井式で予測する場合、 式(3)を以下のように変更すればよいことも分かった。

$$
D_{h}=\sqrt{\left(1+\alpha h_{0}\right) /\left(1+\alpha h_{e q}\right)} ， \alpha=97 \text { (L1 波), or } 75(\mathrm{~L} 2 \text { 波) }
$$

しかし、本論文では、これ以後、模擬地震波 2 波を除き、 $\alpha=25$ と して、31 種の実地震波を応答予測法の検証に用いる。つまり、式(3) を変えずに用いることとする。
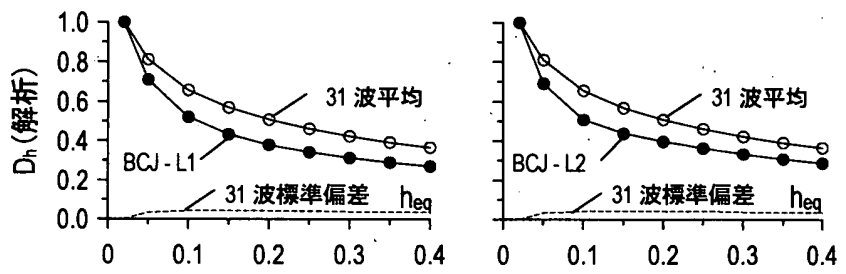

図 631 波の平均値と BCJ-L1およびBCJ-L2 との比較 ( $h_{0}=0.02$ の場合)

\section{3. 最大応答予測の理論と精度検証}

\section{1 予測法の概念}

バイリニア型 1 質点弾塑性系を考慮する (図 7)。初期剛性と 2 次 剛性を $K_{0}, p K_{0}$ 、質量 $M$ とすると、初期 (弾性) 周期 $T_{0}=2 \pi \sqrt{M / K_{0}}$ で ある。地震入力と様々な $T_{0}$ に対する擬似速度応答 (pseudo-velocity) スペクトル $S_{p v}\left(T_{0}, h_{0}\right)$ が既知とする。本章では、弾塑性系の等価線形 化と理論を提案し、精度検証も行う。

このため、塑性化による系の岡性低下 (周期増加) とエネルギ一吸 収増加 (減衰増加) の影響を、それぞれ 3.2 節と 3.3 節に分け論ずる。 すなわち 3.2 節では、減衰定数を初期值 $h_{0}$ のままとして、周期増加 による最大速度の変化を考慮する。 3.3 節では、減哀定数 $h_{0}$ から $h_{e q}$ への増加による最大速度の低減を、 $D_{h}($ 式(3))によって表す。 

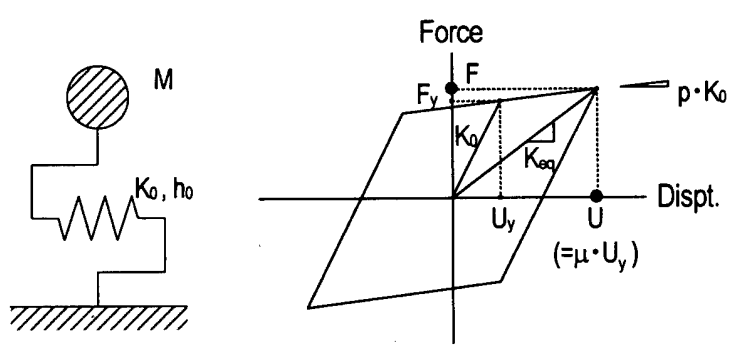

図 7 1 質点モデルと履歴特性

\section{2 等価周期とスペクトル平滑化}

塑性化による剛性低下を考慮し、降伏変形 $U_{y}$ である系の、最大変 形Uに達したサイクルでの等価周期 $T_{e q}$ は、図 7 の割線剛性 $K_{e q}$ と $M$ で表され、最大塑性率 $\mu\left(=U / U_{y}\right)$ を用いれば、

$$
T_{\text {eq }}=T_{0} \sqrt{\mu /(1-p+p \mu)} \quad(\mu>1)
$$

となる。 $T_{e q}>T_{0}$ であり、 $\mu$ が大きいほど $T_{e q}$ が増加する (図 8(a))。 大小サイクルを含む地震応答では、各サイクルの塑性率が様々で あり、サイクル毎の周期は $T_{0}$ と $T_{e q}$ の間で変化すると言える。そこ で系の最大速度は $S_{p v}\left(T_{e q}, h_{0}\right)$ から評価せず、 $T_{0}$ から $T_{e q}$ までの応答ス ペクトル值の平均を用いることにする。これを最大サイクルでの「等 価速度応答スペクトル」值と呼ひ、以下のように求める。

$$
\overline{S_{p v}}\left(T_{e q}, h_{0}\right)=\frac{1}{T_{e q}-T_{0}} \int_{T_{0}}^{T_{T_{p}}} S_{p v}\left(T, h_{0}\right) d T
$$

式(9)の例として二次剛性比 $p=0$ の系が、El Centro NS 波に対し最
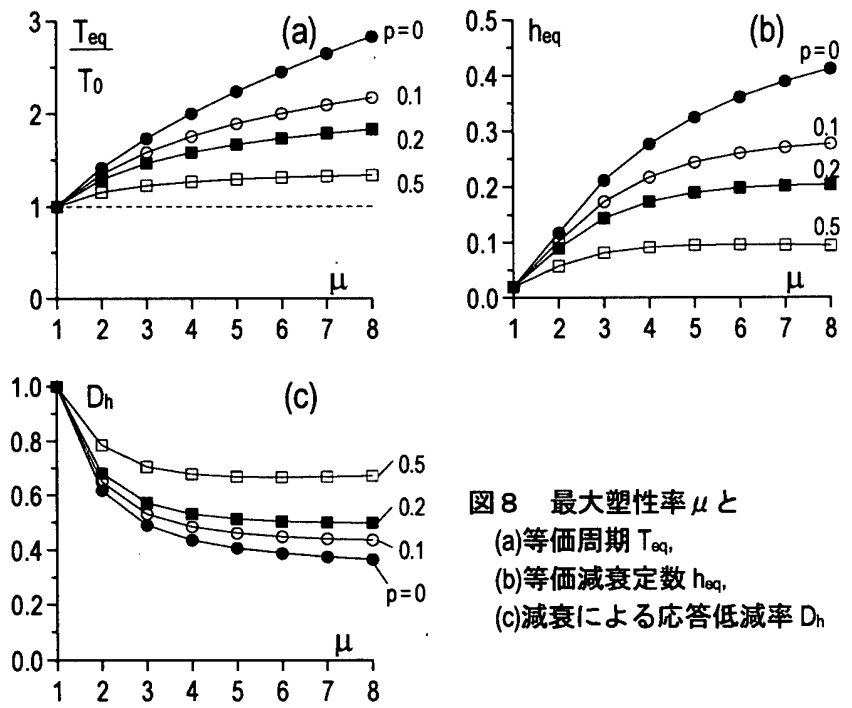

\section{図 8 最大塑性率 $\mu$ と} (a)等価周期 $T_{\infty}$ (b)等価減衰定数 $h_{\mathrm{oq}}$, (c)減衰による応答低減率 Dh

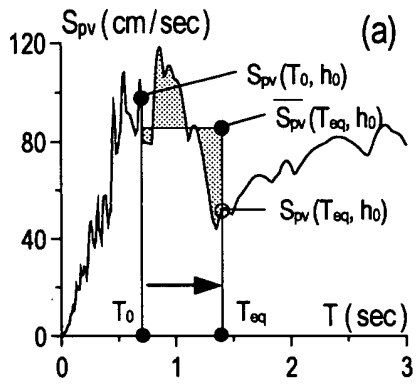

(a)

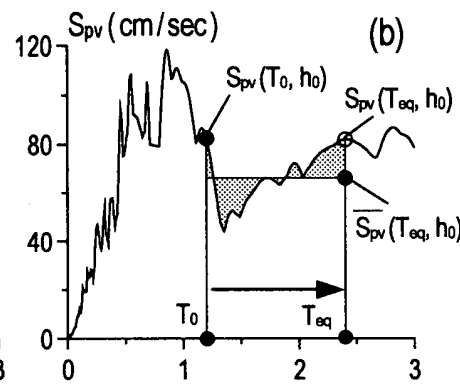

図 9 等価速度応答スペクトル $\overline{S_{p v}}$ の概念图 (EICentro NS $\left.p=0, \mu=4\right)$
大塑性率 $\mu=4$ を示す場合を考える。図9(a), (b)は、それそれ弾性周 期 $T_{0}$ が短い場合、中程度の場合を表している。最大变形時の等価周 期 $T_{e q}$ は、両者とも $2 T_{0}$ である(式(8))。図9(a)は、 $\overline{S_{p v}}$ が $S_{p v}$ よりかな り高く、一方、図9(b)では逆であり、これらは $\left[T_{0}, T_{e q}\right]$ における応 答スペクトル曲線の形状に依存することが分かる。

\section{3 等価減衰とスペクルル低減化}

塑性率 $\mu^{\prime}$ を示すサイクルにおける等価隇衰定数 $h^{\prime}{ }^{\prime}$ は、 履歷吸収 エネルギーと弾性エネルギーの比から、式(10)のように求められる。

$$
h_{e q}^{\prime}\left(\mu^{\prime}\right)=h_{0}+\frac{2(1-p)\left(\mu^{\prime}-1\right)}{\pi \mu^{\prime}\left(1-p+p \mu^{\prime}\right)} \quad\left(\mu^{\prime}>1\right), \text { or } h_{0}\left(\mu^{\prime} \leq 1\right)
$$

3.2 節と同様、大小サイクルを含むランダム応答では、各サイクル の塑性率 $\mu^{\prime}$ は、 0 から最大值 $\mu$ まで様々ある。そこで $h^{\prime}{ }_{e q}\left(\mu^{\prime}\right)$ の平均 を等価減衰定数 $h_{e q}$ とする Newmark-Rosenblueth 式 $\left.{ }^{14)}, 15\right)$ を用いる。

$$
h_{e q}=\frac{1}{\mu} \int_{0}^{\mu} h_{e q}\left(\mu^{\prime}\right) d \mu^{\prime}=h_{0}+\frac{2}{\mu \pi p} \ln \frac{(1-p+p \mu)}{\mu^{p}} \cdot(\mu>1)
$$

明らかに、 $h_{e q}$ は最大サイクルにおける $h_{e q}^{\prime}$ よりも低い。また、 $\mu$ が 大きく $p$ が小さいほど、 $h_{e q}$ は大きい (図 8(b))。

ここで、実地震波の傾向に最も合った式(3) に $h_{e q}$ を代入し、応答 低減率 $D_{h}$ を求める。勿論、 $\mu$ が大きくなると、 $h_{e q}$ が増大するため $D_{h}$ は小さくなる $\left(\right.$ 図 8(c))。この $D_{h}$ で等価速度応答スペクトルを低減 したものを、等価減衰 $h_{e q}$ での系の擬似速度応答スペクトルと考える。 すなわち、

$$
S_{p v}\left(T_{e q}, h_{e q}\right)=D_{h} \overline{S_{p v}}\left(T_{e q}, h_{0}\right)
$$

最大サイクル、つまり周期 $T_{e q}$ の時の最大速度が $S_{p v}\left(T_{e q}, h_{e q}\right)$ である ため、変位・擬似加速度応答スペクトル值が以下のように表される。

$$
S_{d}\left(T_{e q}, h_{e q}\right)=\frac{T_{e q}}{2 \pi} S_{p v}\left(T_{e q}, h_{e q}\right)=\left(\frac{T_{e q}}{2 \pi}\right)^{2} S_{p a}\left(T_{e q}, h_{e q}\right)
$$

以上の定式化を図 10 に要約する。図 9(b)の場合について、最大塑 性率 $\mu$ となる系の最大擬似速度は、図 10(a)の如く $\mu$ に相当する周期 の伸びと応答スペクトル平滑化により等価速度応答を求め (矢印(1))、 それを減衰增加により低減して (矢印(2) 予測する。なお、この過程 を変位で表したものも図 10(b)に示す。

また、この例では、 $T_{e q} / T_{0}=2$ であり (3.2 節)、この比を用いて全て の $T_{0}$ の範囲で数值積分(式(9))を行った結果も図 10 の上側破線で示 す。このように式(9)は、擬似速度応答スペクトルを平滑化した等価 速度応答スペクトルを構築することができ、それに $D_{h}$ を乗じて得ら れる下側破線 (図 10) も、やはり滑らかなものになり、高減衰での スペクトル曲線の平滑化という典型的な傾向と整合したものになる。
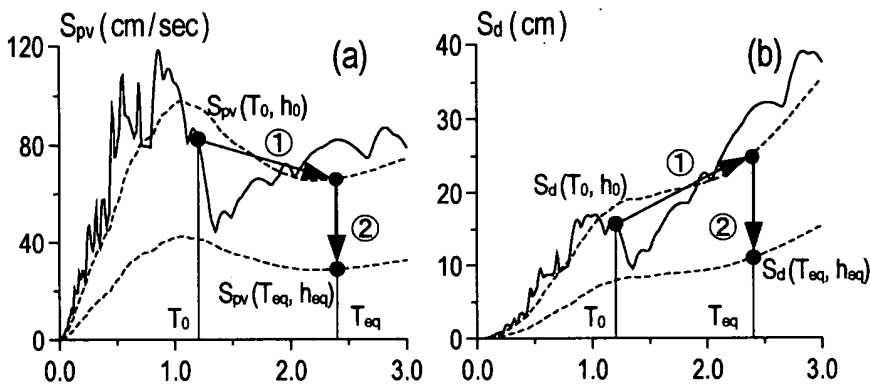

図10 本予測法の算定プロセス（図 9(b)に示した場合について） 
また、弾塑性系のサイクル毎に変わる周期がもたらす最大速度応 答の傾向を、式(9)が概ね予測できることも確認している (付録 3)。 3. 4 他手法の概念と算定法

等価線形化の既往研究は数多いが、本論のように初期減衰での線 形応答スペクトル曲線を低減したものを代用して、予測にまで展開 したものは数少ないが、その先駆的なものとして約 30 年前の柴田 6), ᄁの研究があり、その検証は島崎 ${ }^{12)}$ によってなされている。これ らは剛性低下型の特性を示す RC 骨組を対象としているため、付録 4 にて注积することにし、ここでは、バイリニア履歴特性を対象と したものの代表例を挙げ、本手法との違いを要約する。

Fu \& Cherry $^{10)}$ の方法は、a) サイクル毎の割線剛性の平均を $K_{e q}$ と して $T_{e q}$ を表現する。b) サイクル毎エネルギ一吸収の平均と $K_{e q}$ の 比から $h_{e q}$ を評価する。c) 応答スペクトル形状の影響・平滑化 (3.2 節) を考慮しない。d) $D_{h}$ として式(2)定数 18 を 30 と変えたものを用 いる。本手法に比べ $T_{e q}$ が短く $h_{e q}$ はかなり低い。また、最大サイク ルでの周期を用いないため、応答スペクトルの特徵である最大変 位·擬似速度·擬似加速度の簡便な関係を利用することができない。

2000 年改正基準法での限界耐力計算法 ${ }^{5) 8}{ }^{8}$ は、a) 最大サイクルで の割線剛性を $K_{e q}$ として $T_{e q}$ を表現する。b) 最大サイクルでの履歴 減衰に 0.8 を乗じ、それに $h_{0}$ を加えて $h_{e q}$ とする。c) 応答スペクト ル形状の影響・平滑化を考慮しない。d) $D_{h}$ として式(4)を用いる。
本手法に比べ、 $\mu$ が小の場合 $h_{e q}$ が高いが、他の場合は係数 0.8 の効 果が增して同等となる。また、実地震波での減衰の効果を過大評価 する式(4) を用いるため、 $D_{h}$ は低めとなる。

Newmark \& Hall の変位一定則・エネルギ一一定則 ${ }^{13)}$ は、それぞれ 弾塑性系と弾性系の最大変位・エネルギ一が等しいと仮定し、弾塑 性䒺応答を低減衰の線形応答スペクトル自体で予測する方法である。 等価線形化手法の範疇にないが、線形応答スペクトルに基づく簡便 な手法として挙げられる。これらは、a) 等価剛性や減衰定数の評価 を行わない。b) 最大塑性率 $\mu$ や 2 次剛性比 $p$ が最大変形に及ぼす影 響を加味しない。c) 応答スペクトル形状の影響を考慮しない。d) 必 ずしも弾性域の減衰定数を応答スペクトルに用いるとは限らない。

\section{5 実地震波を用いた精度検証}

上記の如く他の等価線形化手法は、周期伸びと減衰増加の影響を 2 ステップで加味する点で本手法と同等だが、具体的な算定法が異 なる。よって、これらの予測結果を時刻歷解析結果と比較してみる。

1 質点弾塑性系 (図 7) で、初期減衰 $h_{0}=0.02 、 29$ 種の初期周期 $T_{0}$ (0.1 秒間隔で 0.2〜3.0 秒) を用いる。また、それぞれにつき 3 種の 2 次剛性比 $p=0,0.2,0.5$ を考え、各々の地震波で 3 種の最大塑性率 $\mu=$ 2, 4,6 を示すよう系の降伏力を設定した。また、31 種の実地震波 (表 2) を用いる。以上、総計 8,091 種類 $(=29 \times 3 \times 3 \times 31)$ の系を作成し: 時刻歷解析および本手法・他手法による応答予測を行った。

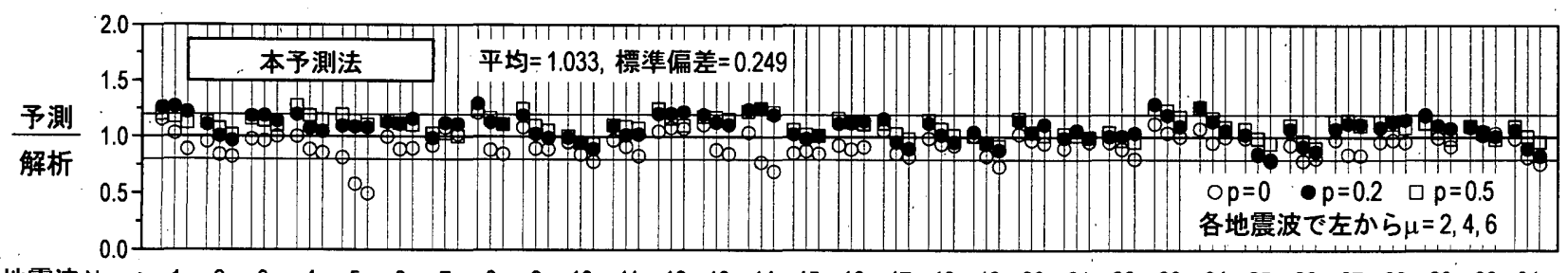

(a)

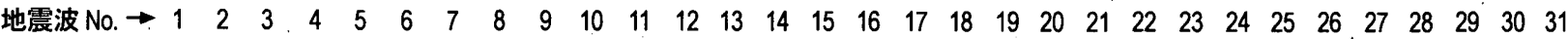
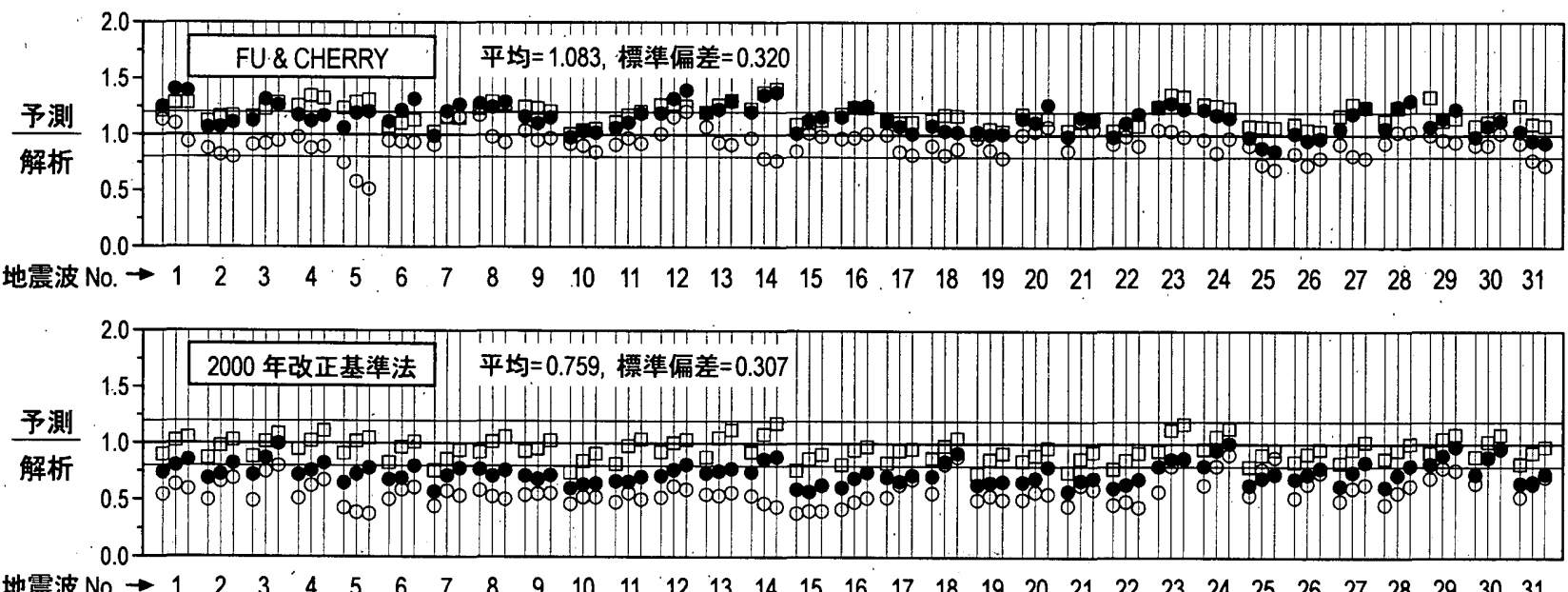

地震波 No. $\rightarrow \begin{array}{llllllllllllllllllllllllllllllll}1 & 2 & 3 & 4 & 5 & 6 & 7 & 8 & 9 & 10 & 11 & 12 & 13 & 14 & 15 & 16 & 17 & 18 & 19 & 20 & 21 & 22 & 23 & 24 & 25 & 26 & 27 & 28 & 29 & 30 & 31\end{array}$

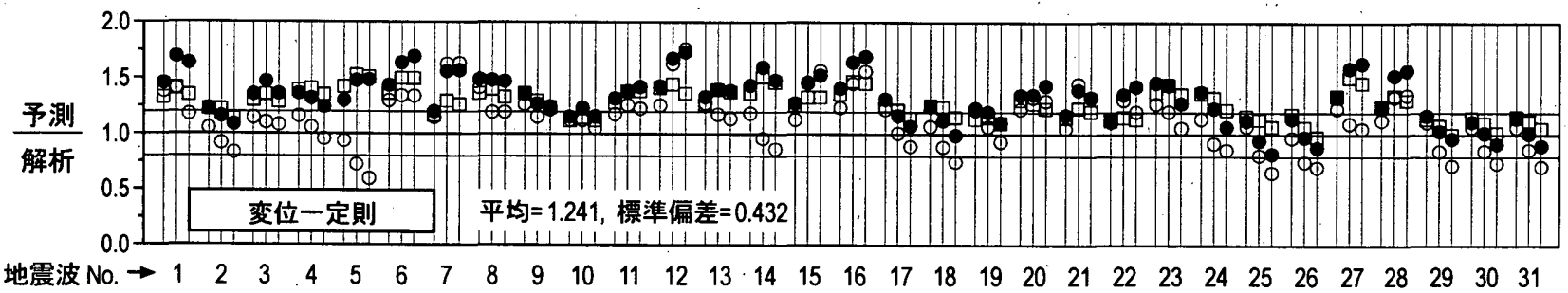

図 11 各手法と非線形解析との比較 （各地震波において左から $\mu=2,4,6$, 各手法につき 8,091 ケースの統計） 
なお、本手法では、式(8), (11)に $h_{0}, T_{0}, p, \mu$ を代入して等価周期・ 減衰を求め、各地震波の初期減衰応答スペクトルに式(9), (12)を適用 して $S_{p v}\left(T_{e q}, h_{e q}\right)$ を得た後、式(13)により最大变位 $S_{d}$ を予測した。詳 細は異なるが、他の等価線形化手法の場合にも同様な手順を踏んだ。

図 11(a)は、本手法の精度を地震波 No.1〜31 (表 2) について示して いる。各地震波で、 $p, \mu$ の組み合わせごとに、上記 29 種の周期で求 めた予測値(式(13)) と時刻歷解析值の比の平均をプロットした。本 手法は、概水時刻歴解析と良い一致を示し、最大変位の傾向を捉え ているといえ、また、図中に示したように 8,091 ケースの平均は、 他手法 (図 11(b)〜(d)) に比べ 1 に近く、かつその標準偏差は最も低 くなっており、バラツキの少ない安定した精度を示している。

Fu-Cherry 法 (図 11(b)) も、本手法と同様に応答傾向を捉えている が、応答スペクトル平滑化という概念をもたないため、多少標準偏 差が高く精度にバラツキがみられる。2000 年改正基準法 (図 11(c)) では、全体に最大変位を低めに予測している。弾性挙動に近づく $p=$ 0.5 では概ね合っているが、 $p=0$ では予測值は解析值のほぼ半分て あり、精度が $p$ に大きく依存しているといえる。 Newmark-Hall 法に ついては、紙幅の都合により変位一定則 (図 11(d)) のみを示すが、 精度が地震波に強く依存している。

さらに表 3 により、短周期 $(0.2 \sim 0.6$ 秒)、中周期 $(0.7 \sim 1.5$ 秒)、中 長周期 (1.6 3.0 秒) の領域ことに、各手法の精度を検証する。変位 一定則・エネルギー一定則については、予測に用いる線形応答スペ クトルの減衰定数を 0.02 と 0.05 の 2 パターンとした。

本手法は、長周期で予測值がやや下がるが (付録 2 参照)、全体に 周期領域によらない安定した精度を保っているといえる。Fu-Cherry 法では精度がやや落ち、バラツキも大きくなるが、周期領域ことの 変化はあまり無い。2000 年改正基準法では、中周期以上で予測が解 析を大きく下回っている。中周期以上、そして短周期でそれぞれよ い精度を示すといわれる変位一定則とエネルギ一一定則の場合、減 衰定数 0.02 の線形応答スペクトルによる予測では、解析值をかなり 上回っており、極端な誤差も認められる (表 3)。一方において、減 衰定数 0.05 を用いた予測では精度が向上するが、対象構造の初期減 衰 $h_{0}=0.02$ であることを考えると、整合性に欠けていると言える。

\section{表 3 周期領域ごとの各手法と非線形解析との精度比較} 上段：平均値，下段：標準偏差

\begin{tabular}{|c|c|c|c|c|}
\hline & $0.2-0.6(\mathrm{sec})$ & $0.7-1.5(\mathrm{sec})$ & $1.6-3.0(\mathrm{sec})$ & $0.2-3.0(\mathrm{sec})$ \\
\hline \multirow{2}{*}{ 本予測法 } & 1.082 & 1.069 & 0.995 & 1.033 \\
\hline & $(0.246)$ & $(0.256)$ & $(0.240)$ & $(0.249)$ \\
\hline \multirow{2}{*}{ Fu \& Cherry } & 1.080 & 1.122 & 1.060 & 1.083 \\
\hline & $(0.322)$ & $(0.339)$ & $(0.305)$ & $(0.320)$ \\
\hline \multirow{2}{*}{$\begin{array}{c}\text { 2000年 } \\
\text { 改正基隻法 }\end{array}$} & 0.939 & 0.787 & 0.682 & 0.759 \\
\hline & $(0.325)$ & $(0.299)$ & $(0.275)$ & $(0.307)$ \\
\hline \multirow{2}{*}{$\begin{array}{c}\text { 変位一定則 } \\
\text { (2\%减衰で予測) }\end{array}$} & 1.019 & 1.225 & 1.303 & 1.241 \\
\hline & $(0.353)$ & $(0.424)$ & $(0.437)$ & $(0.432)$ \\
\hline \multirow{2}{*}{$\begin{array}{c}\text { 変位一定則 } \\
\text { (5\%減衰で予測) }\end{array}$} & 0.780 & 0.984 & 1.070 & 0.993 \\
\hline & $(0.228)$ & $(0.289)$ & $(0.331)$ & $(0.320)$ \\
\hline \multirow{2}{*}{$\begin{array}{l}\text { エネルギー一定則 } \\
\text { (2\%減衰で予測) }\end{array}$} & 1.495 & 1.873 & 1.951 & 1.848 \\
\hline & $(0.547)$ & $(0.735)$ & $(0.801)$ & $(0.760)$ \\
\hline \multirow{2}{*}{$\begin{array}{l}\text { エネルギー一定則 } \\
\text { ( } 5 \% \text { 減衰で予测) }\end{array}$} & 1.144 & 1.463 & 1.601 & 1.479 \\
\hline & $(0.356)$ & $(0.519)$ & $(0.623)$ & $(0.577)$ \\
\hline
\end{tabular}

\section{4. 最大応答の簡易予測手法}

前章において、多くの検証例により本理論の精度を実証した。こ の理論により、初期減衰定数 $h_{0}$ の線形応答スペクトルを用いた簡易 な応答予測手法が様々に展開できることを、本章で述べる。

\section{1 基本的な予測手法}

初期減衰定数・周期 $h_{0}, T_{0}$ と降伏変形と力 $U_{y} F_{y}$ をもつ弾塑性系に おいて、その最大変位と力 $U, F$ は、式(12),(13)より、

$$
U=D_{h}\left(T_{e q} / 2 \pi\right) \overline{S_{p v}}\left(T_{e q}, h_{0}\right), \quad F=M \cdot U \cdot\left(2 \pi / T_{e q}\right)^{2}
$$

手計算で、例えば以下のように $U, F$ が得られる。まず、 $T_{e q}=T_{0}$ として線形応答スペクトルから $U$ を求める。次に、 $\mu\left(=U / U_{y}\right), T_{e q}$ (図 $8(\mathrm{a})$ または式 $(8)), D_{h}\left(\right.$ 図 8(c)または式(3)), $\overline{S_{p v}}\left(T_{e q}, h_{0}\right)$ を算定し、U.の 再評価(式(14a)) を1 2 度繰り返す。Uの収斂後、 $F$ を求める(式(14b))。 なお、厳密な $\overline{S_{p v}}\left(T_{e q}, h_{0}\right)$ の評価は必要無い。これは、目分量でほ ほ平均值 $\overline{S_{p v}}$ (図9参照) が評価できるからである。

以上の線形解析で用いた $\mu や T_{e q}$ は、弹塑性系の最大変形時の履歴 曲線に基つくくため、式(14)の別表現として、次式も有用である。

$$
U=\mu U_{y}, \quad F=F_{y}(1-p+p \mu)
$$

\section{2 変位·せん断力倍率の予測手法}

弾塑性系の免震・制振構造などの設計では、与えられた地震入力 に対し $\mu=1$ (弾性) と仮定して得た応答值を基準とし、 $\mu$ の增加によ る応答低減を検討することがよくある。弹性系の最大変位と力を $U_{e l}$ $F_{e l}$ とすると、式(12) (14)より、明らかに

$$
\frac{U}{U_{e l}}=D_{h} \frac{T_{e q}}{T_{0}} \frac{\overline{S_{p v}}\left(T_{e q}, h_{0}\right)}{S_{p v}\left(T_{0}, h_{0}\right)}, \frac{F}{F_{e l}}=\frac{U}{U_{e l}}\left(\frac{T_{0}}{T_{e q}}\right)^{2}
$$

式(16a,b)左辺の比をそれぞれ変位・せん断力倍率、総じて応答倍 率と呼ぶ。ある $U_{y}, F_{y}$ をもつ弾塑性系の応答予測 (4.1 節)、そして、 逆に目標応答に必要な $U_{y}, F_{y}$ の設計などを包含する便宜的手法とし て、様々な $\mu$ での応答倍率のプロットを利用することが考えられる。

このようなグラフでは、 $\mu=1$ で変位・せん断力倍率ともに 1 とな り、 $\mu>1$ で、せん断力倍率は減るが、変位倍率は $\mu$ 值やスペクトル などに依存する。 $U_{e l}, F_{e l}$ は、周期 $T_{0}$ における応答スペクトル值から 求められるので、このグラフから $U, F, \mu$ 対応が分かり、よって 式(15)から $U_{y}, F_{y}$ にも言及できる。さらに、4.1 節で述べた収敛計算 の必要も無い。これらの点につき、次節で詳細に述べるとにする。

\section{3 スペクトルー定の場合における予測手法}

周知の傾向として、擬似加速度応答、擬似速度応答、変位応答又 ペクトルがそれそれれ定の場合を考慮する。図 12 に示すように、こ れらはそれそれれ $S_{p v}$ が周期に比例、一定、反比例する場合である。以 上と式(16a) から、変位の予測值 Uは次式で表される。

$$
\begin{aligned}
& \frac{U}{U_{e l}}=D_{h} \frac{T_{e q}}{T_{0}} \frac{T_{e q} / T_{0}+1}{2} \quad\left(\dot{S}_{p v} \propto \text { 周期 }\right) \\
& \frac{U}{U_{e l}}=D_{h} \frac{T_{e q}}{T_{0}} \quad\left(S_{p v}=\text { 一定 }\right) \\
& \left.\frac{U}{U_{e l}}=D_{h} \frac{T_{e q}}{T_{0}} \frac{\ln \left(T_{e q} / T_{0}\right)}{T_{e q} / T_{0}-1} \quad \text { (S } S_{p v} \propto 1 / \text { 周期 }\right)
\end{aligned}
$$


加速度一定
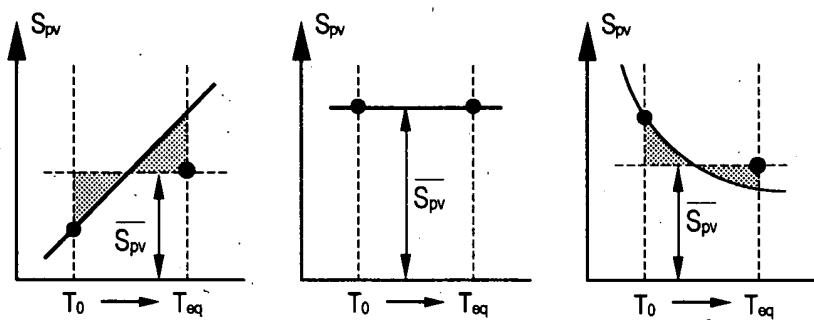

図 12 擬似加速度・擬似速度・変位応答スペクトル一定の場合の $\overline{\mathrm{S}_{\mathrm{pv}}}$

また、対応するせん断力 $F$ は、式(16b)で与えられる。

図 13(a)は、 $S_{p v}$ が一定の場合(式(17b))を示しており、初期減衰定 数 $h_{0}=0.02 、 2$ 次剛性比 $p=0.2$ を想定している。 4.2 節で述べたよう に、様々な $\mu$ に対し $U / U_{e l}, F / F_{e l}$ を表しており、また、折れ曲がり(降 伏)点の座標 $U_{y} / U_{e l}, F_{y} / F_{e l}$ は、式(15), (17b)から容易に求まる。

図 13(a)は、ある地震入力における弾塑性系の降伏変位・せん断力、 2 次剛性比等の構造パラメーター、そして最大塑性率 最大変位. せん断力などの応答パラメーターの関連を示すものであり、様々に 活用できる。例えば最大応答を求める場合、まず弾性系の最大応答 $\left(U_{e l}, F_{e l}\right)$ を求め、 $F_{y} / F_{e l}=0.25$ と決めると、降伏点の座標 $\left(U_{y} / U_{e l}, F_{y} /\right.$ $\left.F_{e l}\right)=(0.25,0.25)$ は決定され、さらに降伏点から傾き $p=0.2$ の斜線を 引けば、曲線との交点が、求める応答値 $\left(U / U_{e l}, F / F_{e l}\right)=(0.83,0.37)$ と なり、弾塑性系の最大応答予測が完了する。また、例えば $p=0$ では、 いわゆる $D_{s}$ 值 $\left(=F / F_{e l}\right)$ に対応する $U / U_{e l}$ ，つまり変位を予測できる。 さらに、式(17) を用い、様々な 2 次剛性比 $p$ における変位・せん 断力倍率 $U / U_{e l}, F_{y} / F_{e l}$ の関係を図 13(b)〜(d)に表す。また、各図に は $S_{p v}$ が周期に比例、一定、反比例する 3 ケースを示している。

擬似加速度応答スペクトル一定、つまり $S_{p v} \propto$ 周期の場合、変位が 弾性系の変位を上回る場合が殆どであり、特に 2 次剛性比 $p$ と降伏 力 $F_{y}$ が低い場合に著しく增加する。これは、式(17a)が $T_{e q}$ の二乗項 をもつため、塑性化による $T_{e q}$ の増加が強く影響するからである。
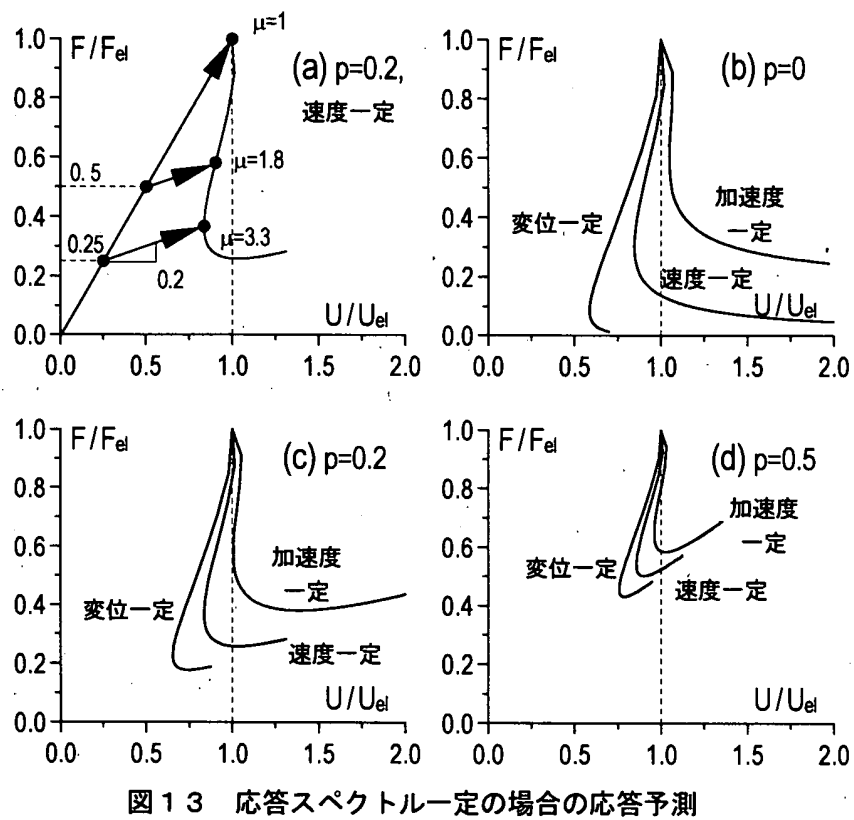

擬似速度応答スペクトル $S_{p v}$ 一定の場合、 $p, F_{y}$ が極端に低くない 限り、変位か弾性系の変位以下となる。これは、式(17b)が $T_{e q}$ の一 乗項のみ含むため、応答低減率 $D_{h}$ が効いてくるからである。

変位応答スペクトル一定、つまり $S_{p v} \propto 1 /$ 周期の場合、変位が弾性 系の変位をかなり下回る場合が多い。これは、式(17c)で $T_{e q}$ の増加 があまり反映せず、 $D_{h}$ の低下の影響がより著しいからである。

これらから、一般に弾塑性系は速度応答や変位応答スペクトルが 一定の領域、つまり中長周期の構造のほうが有利であるといえる。

なお、加速度応答一定から速度応答一定に推移する点の周期を $T_{1}$ また速度応答一定から変位応答一定に推移する点の周期を $T_{2}$ とし、 上述と異なり $T_{1}$ もしくは. $T_{2}$ が周期領域 $\left[T_{0}, T_{e q}\right]$ に含まれる場合を 考慮する。この時、応答予測は式(17)と同様に、以下および式(16b) で表される。

$$
\begin{array}{ll}
\frac{U}{U_{e l}}=D_{h} \frac{T_{e q}}{T_{0}}\left[\frac{T_{1}}{T_{0}}-\frac{\left(T_{1} / T_{0}-1\right)^{2}}{2\left(T_{e q} / T_{0}-1\right)}\right] \quad\left(T_{0}<T_{1}<T_{e q}\right) \\
\frac{U}{U_{e l}}=D_{h} \frac{T_{e q}}{T_{0}} \frac{\left(T_{2} / T_{0}\right)\left[1+\ln \left(T_{e q} / T_{2}\right)\right]-1}{T_{e q} / T_{0}-1} \quad\left(T_{0}<T_{2}<T_{e q}\right)
\end{array}
$$

\section{4 スペクトルほぼ一定の実地震波による精度検証}

31 実地震波の中から、周期領域 $\left[T_{0}, T_{e q}\right], h_{0}=0: 02$ において、上記 スペクトルが概ね一定のものを弾塑性時刻歴解析に用い、予測式 (17) と比較した。加速度応答一定、速度応答一定、変位応答一定の スペクトル曲線の起点をそれぞれ $T_{0}=0.3,1.0,2.0$ 秒と設定した。表 4 に、選んだ 19 種の地震波の番号 (表 2 参照) を示す。

図 14 左段に、弾性周期 $T_{0}$ において基準化した各地震波の応答ス ペクトルを示す。実地震波ゆえにスペクトル量の変化は免れないが、 統計的に概ね一定なこと (図 14 左段) や、2.4 節に述べた模擬地震波 のもつ問題などを勘案し、これら 19 波を用いることにした。

弾塑性系には、 3 種の 2 次剛性比 $p=0,0.2,0.5$ そして 9 種の $F_{y} / F_{e l}$ $=0.1 \sim 0.9$ (0.1 刻み) を考慮した。検討総数は $513(=19 \times 3 \times 9)$ である。

図 14 右 3 段に、最大変位 $U / U_{e l}$ と最大力 $F / F_{e l}$ との関係を示す。 プロットは時刻歴応答の平均值と標準偏差、実線は予測式(17)を示

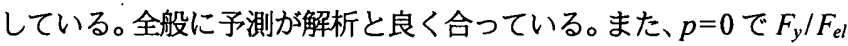
が小さいと、残留変形などの影響から多少精度は落ちるが、概ね解 析の傾向を捉えており、本手法は 3 種の応答スペクトルが一定とい う条件のもとでも、良好な精度をもつと言える。

以上、擬似速度応答スペクトル曲線が不規則に変化する場合 $(3.5$ 節)、そして上記のように滑らかに変化する場合や一定の場合に関わ らず、等価速度応答スペクトルという平均化の概念を与えることで、 一貫して安定した予測精度が得られた。これらの結果および算定プ ロセスにおける各段階の検証結果は、応答スペクトル值をそのまま 用いるのではなく、本手法のように、応答スペクトル曲線の形状に よる影響を加味することの必要性を示していると思われる。

表 4 応答スペクトル条件とその入カ地震波および弾性周期

\begin{tabular}{|c|c|c|}
\hline スペクトル条件 & 弾性周期 $\mathrm{T}_{\mathrm{o}}(\mathrm{sec})$ & 入力地震波 \\
\hline $\mathrm{S}_{\mathrm{pa}}=$ 一定 & 0.3 & 8 波 (No.17, 19,22,24, 25, 26, 29,30) \\
\hline $\mathrm{S}_{\mathrm{pv}}=$ 一定 & 1.0 & 5 波 (No.3, 10,18,23,31) \\
\hline $\mathrm{S}_{\mathrm{d}}=$ 一定 & 2.0 & 6 波 (No.7, 10,14,20,21, 28) \\
\hline
\end{tabular}



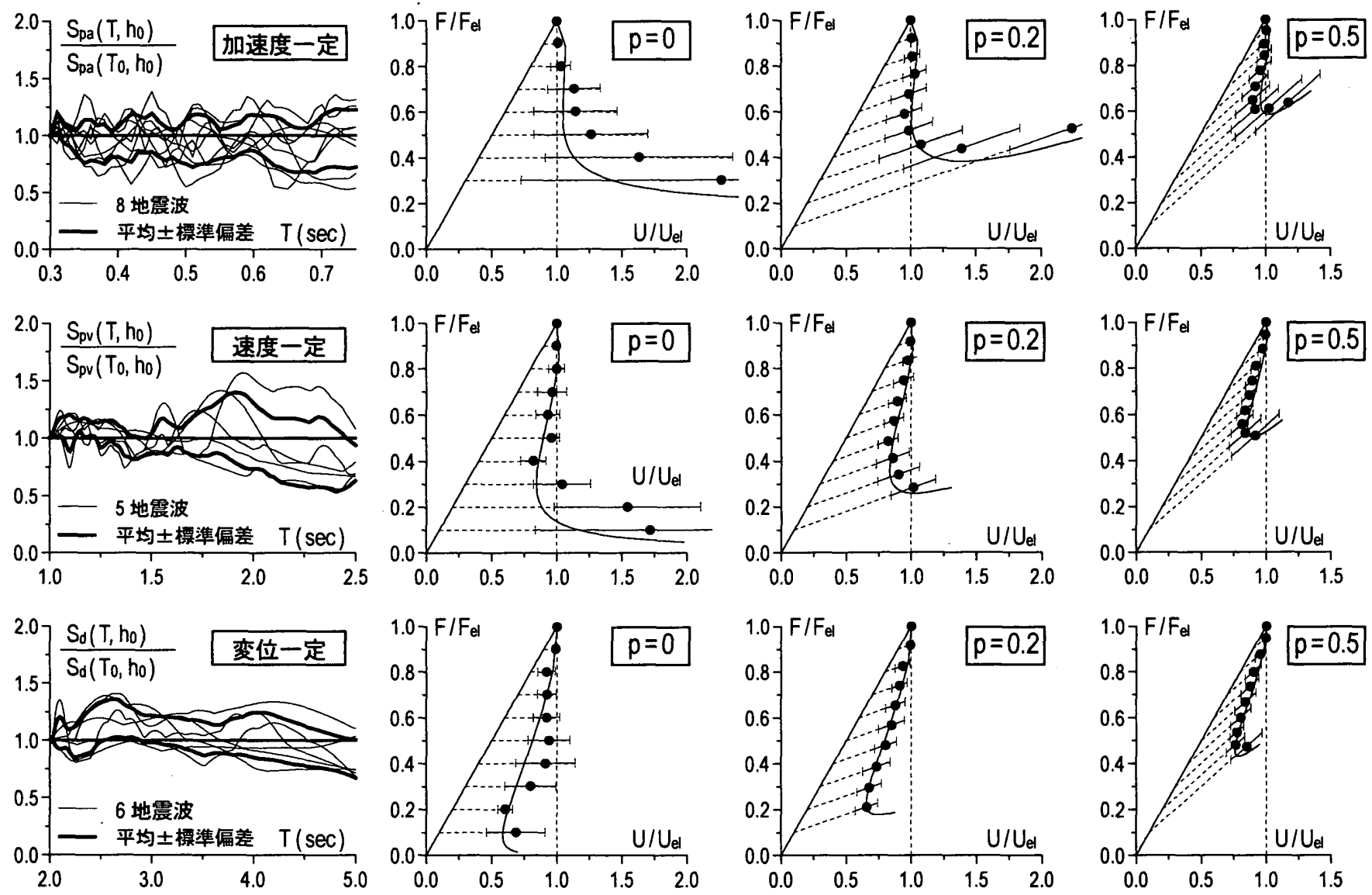

図 14 スペクトルー定の場合における予測と時刻歴解析の比較
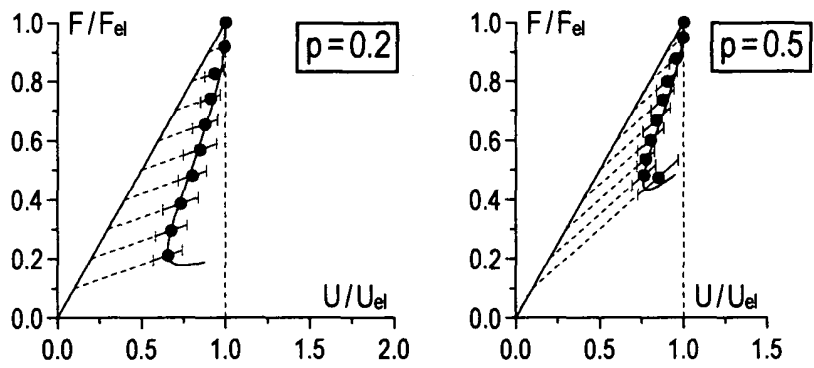

予測式 標準偏差 手時刻歴解析平均值; 513 ケースの統計）

\section{5. おわりに}

応答スペクトルを用いた本等価線形化手法について、その理論的 背景と精度について論じた。以下にまとめる。

(1) 減衰の付加による変位応答スペクトルの低減率 $D_{h}$ について、33 波の地震波を用いた解析結果と既往の4 予測式との比較を行い、 本予測式が解析と良く一致することを示した。また、模擬地震 波における応答低減の傾向が、実地震波よりも顕著なことが判 明した。今後の模擬地震波の作成・使用に際し、この問題に留 意する必要がある。また、実地震波の継続時間、応答スペクト ル種別、固有周期と低减率との関係について考察を行った。

(2) 塑性化による固有周期の変化、入力地震動の応答スペクトル形 状の影響、およびランダム応答時の履歴減衰を考虑して、応答 予測法を構築した。さらに、他の等価線形化手法ならびに変位 一定則、エネルギー一定則による予測法を交えた精度検証を行 い、本手法が応答スペクトル形状や周期によらず、非線形応答 に対し精度よく予測ができることを示した。

(3) 本手法をさらに理論展開することにより、応答スペクトルがー 定の場合について、弾塑性構造の応答傾向に関し、等価周期や 等価減衰を用いて、簡潔に表現することができた。そのため、 本手法は、構造物の性能幅を包括的に取り扱うことができ、最 大応答予測や設計において有効であると考えられる。

なお、本手法は従来の等価線形化手法と同様、経験的な精度調整 に基づく面もあるため (1.2 節)、非常に多数の実地震波や一質点構造 を用いて詳細な精度検証を行った。少なくともこの検証に用いた範
囲である初期周期 $0.2 \sim 3.0$ 秒、2 次剛性比 $0 \sim 0.5 、 そ し て$ 最大塑性 率 1〜6で、本手法は適用可能であると思われる。

就群:

本研究は、文部科学省科学研究費基盤研究 $\mathrm{A}$ 「制振構造 : 性能限界の究明と包括 的設計法の構築」(研究代表者 : 笠井和彦) の補助をうけた。東京工業大学翠川三郎 教授には、地霞波テータや貴重な御助言を頂きました。アイティールフレーン社の 大原和之氏には、御劦力および有益な御助言を頂きました。ここに深謝いたします。

\section{参考文献:}

1) 笠井和彦, 渡沐厚:等価線形化手法による応答予測, 動的外乱に対する設計一現状と展望一，日 本建築学会, pp.156-166, 1999

2）笠井和彦:シンポジウム主旨及び制振性能に関する私見，2000 パツシブ制振構造シンイ゚ジウム 論文集, 東京工業大学建榮物理研究センター, pp.61-76,2000.3

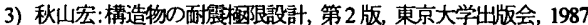

4) Kasai, K., Fu, Y., and Watanabe, A. "Two Types of Passive Control Systems for Seismic Damage Mitigation" Joumal of Structural Engineering ASCE 122 [10], 501-512, 1998

5）建設省住宅局建築指導課: 平成 12 年 6 月施行 改正建案基售法 (2 年目施行) の解锐。 2000.7

6) 柴田明徳: 等洒湶形系による非線形地霞㐫答の解析に関寸る一考察, 東北大学建学学報, 第 16 号, pp.27-39, 1975

7) 柴田明德:最新建築学シリーズ9 最新而震構造解析, 森北比版, 1981

8）五十田博，緑川光正，中澤俊幸:工学的基盤の加速度応答スペ外ルを用いた建策物の耐震性

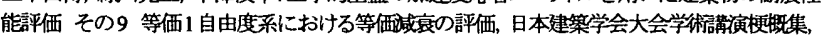
1999.9

9) Hanson, R.D. and Jeong, S.M. "Design Procedure Utilizing Supplemental Energy Dissipation Devices for Improved Building Peformance." Proc. 5th U.S. Nat'l Conf. on Earthiq. Eng 517-526, 1994

10) Fu, Y. and Cherry, S. "Simplified Seismic Code Design Procedure for Friction-Damped Steel Frames." Can. J. Civ. Eng. Vol.26, pp.55-71, 1999

11) FEMA "NEHRP Guidelines for the Seismic Rehabilitation of Buildings and Commentaries." FEMA274 Reports, Building Seismic Safety Council, Washington D.C., 1998

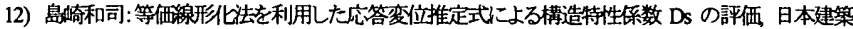
学会構造系論文集, No.516, pp.51-57, 1999.2

13) Newmark N.M. and Hall W.J. "Seismic Design Criteria for Nuclear Reactor Facilities." Report No.46, Building Practices for Disaster Mitigation, National Bureau of Standards, U.S. Department of 
Commerce, 1973

14) Newmark N.M. and Rosenblueth, E. "Fundamentals of Earthquake Engineering" Prentice-Hall Inc.; 1971

15) Iwan, W.D. and Gates, N.C. "Estimating Earthquake Response of Simple Hysteretic Structures." Joumal of the Earthquake Mechanics Division, ASCE, pp.391- 405, 1979

16) Iwan, W.D. "Estimating Inelastic Response Spectra from Elastic Spectre Earthquake Engineering and Structure Dynamics." pp.375-388, 1980.8

17) Gulkan, P. and Sozen, M.A. "Inelastic Response of Reinforced Concrete Structures to Earthquakes." ACI Joumal, 71-12, pp.604-610, 1974

18) Freeman, S.A: "Prediction of Response of Concrete Buildings to Severe Earthquake Motion." Douglas McHenry International Symposium on Concrete and Concrete Structures, SP-55, ACL, Detroit, MI, pp.589605, 1974

19) Shibata, A and Sozen, M. "Substitute Structure Method for Seismic in R/C." Proceedings, ASCE, Vol. 102 St 1,1976

20) 石丸辰治: 構造物の動的解析, 17-7.2. バイリニア履歴系の地震動に対する挙動, 建築技術, No.384, 1983.8

21）中村友紀子、壁谷澤寿海:地霔動特性に基づく最大塑性变位応答に関する研究，構造工学論文 集, pp.485-492, 1997. 3

22) 伊藤浩資, 笠井和彦: 減衰定数に上る応答スペクトル低諴に関する統計的検討, 日本建築学会 大会学術諎福梗概集, B-2, pp.367-368, 2002.8

23) Bolt, B.A. "Duration of Strong Ground Motion" 5th World Conference on Earthquake Engineering Rome 1973

24) A.IJ. "Earthquake Motion and Ground Conditions." pp.157-189, 1993.9

25) Trifunac, M.D. and Brady, A.G "A Study on Duration of Strong Earthquake Ground Motion", Bulletin of the Seismological Society of America, Vol.65, No.3, pp.581-626, June 1975

26) 荒川総一郎他:公団住宅の入力評価に関する研究(その 2 設計指針案の概要), 日本建築学会 大会学術講演梗概集, pp.777-778, 1984

27) 大崎㮌彦他: 堿衰定数と応答スペクトル形状との関係, 日本建築学会大会学術講演梗概集, pp.607-608, 1978. 9

28) 日本建築学会:建築耐霞設計における保有水平耐力と变形性能 (1990), 1990.10

\section{付録1 太答スペクトルの低隇率に関する詳細な考察}

変位・擬似速度・擬似加速度応答スペクトル $S_{d}, S_{p v}, S_{p a}$ に共通な低減率は、速度 加速度応答スペクトル $S_{v}, S_{a}$ それそれの低減率と対比し、周期 0.2 3 秒の間で周期 にあまり依存しないため、減衰定数のみの関数である $D_{h}$ (式(3))で予測可能である と、2.1節で述へた。

一方で、既往文献には、減衰定数のみでなく、(1)固有周期 $T^{26)}$, (2)力地震波の継 続時間 $t$, (3)継続時間 $t$ と固有周期 $T$ との比 $t / T$ により低減率が異なるとするものも ある $\left.{ }^{212} 27 \mathrm{~h} 28\right)$ 。そこで、各ズペクトル量に対する減衰定数および他パラメーター(1) 〜(3)の影響を検討する。表 2 の 31 実地霞波で減衰定数 $h=0.02 \sim 0.4$, 周期 $0.2 \sim 3.0$ 秒を考慮する (計 78,399 ケース)

(1) 固有周期 $T$ の低減率への影響

\section{$h_{0}=0.02$}

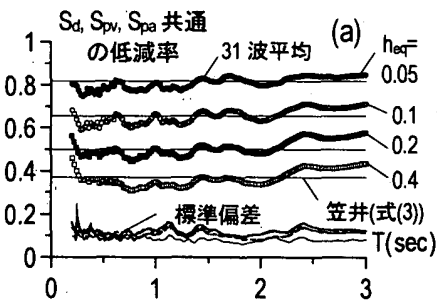

(c)

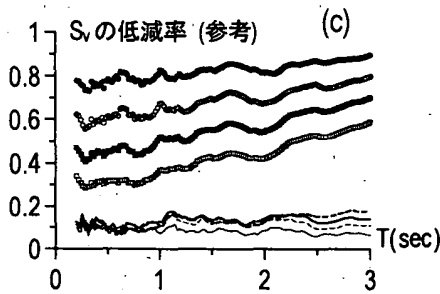

(e)

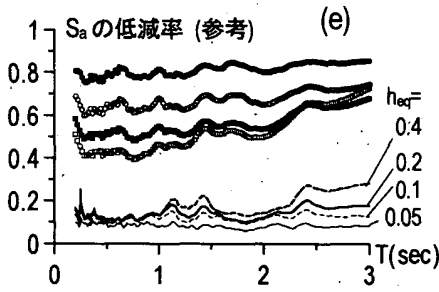

\section{$h_{0}=0.05$}

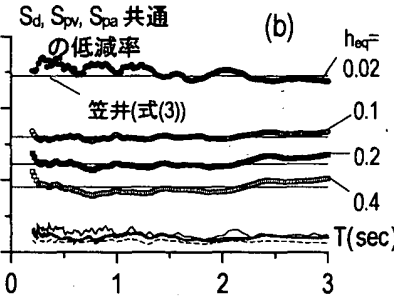

(d)
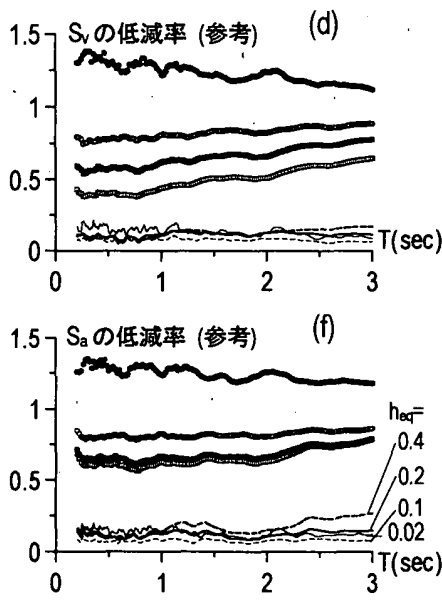

图 A-1 周期 $T$ と $S_{d}, S_{v}, S_{a}$ の低減率との関係 (各周期での 31 波平均、標準偏差) (実線：S $\mathrm{S}_{\mathrm{d}} \mathrm{S}_{\mathrm{p},}, \mathrm{S}_{\mathrm{pa}}$ に対する笠井式(式(3))、プロット：各周期での 31 波平均、実線・破線 : 各周期での 31 波の標準偏差
図 A-1 に $S_{d}\left(S_{p v}, S_{p a}\right.$ と共通), $S_{w} S_{a}$ それそれの低減率の 31 波平均と標準偏差の周期に 対する関係を示すか、傾向が明らかに異なる。S $S_{d}$ の低減率が安定しているのに対比 し、 $S_{v}, S_{a}$ の低隇率は周期 $T$ が長いと増加し、その傾向は高隇衰ほど著しい。また、 特に $S_{a}$ では長周期・高減衰での低減率の標準偏差が大きいが、これは高い粘性によ り応答の自由振動成分よりも強制振動成分が卓越し、かつ構造が軟らかいため、そ の相対速度が地震波パルスに敏感に対応し粘性力が上昇するためである。これと対 照的に $S_{d}$ では周期、減衰、地震波による標漸偏差は小さくほほ一定であり、よって $S_{d}, S_{p v}, S_{p a}$ の低減の予測は、 $S_{v}, S_{a}$ を対象とするより簡便で誤差が少ない。

また、図 A-2(a), (b)に、それそれ $S_{v}$ 低減率と $S_{a}$ 低減率の $S_{d}, S_{p v} S_{p a}$ 共通の低減率に 対する比を示すが、これらは長周期・高減衰において高い。さらに図A-3(a)，(b)に $S_{\nu}$ と $S_{p v}$ の比、 $S_{a}$ と $S_{p a}$ の比を示すが、やはり高減衰・長周期で高くなる。以上を子 まえ、 $S_{d}, S_{p v} S_{p a}$ の低隇は減衰定数のみで予测可能だが、 $S_{v}, S_{a}$ の場合、少なくとも周 期 $T$ の影響も考慮すべきと言える。

(2) 地震波継続時間 $i$ の低減率への影箘

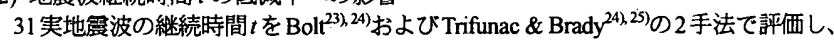
その低減率との相関をみた。Bolt の手法では、入力加速度がそれそれ最初と最後に $0.05 \mathrm{G}\left(=49 \mathrm{~cm} / \mathrm{sec}^{2}\right)$ となる時点の間の長さを $t$ とし、Trifunac \& Brady の方法は、入 力加速度の 2 乗累積値がそれそれ $5 \%, 95 \%$ に達する時点の間の長さを $t$ とする。
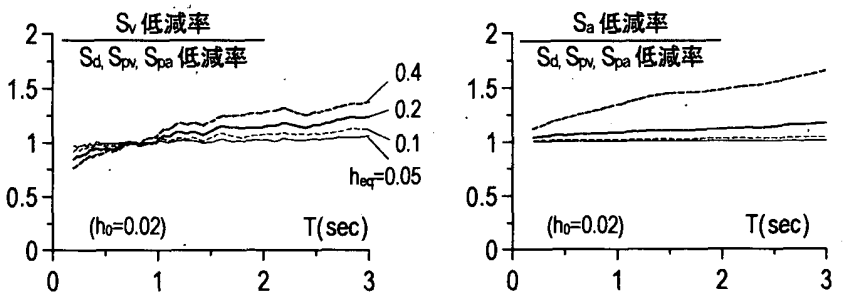

图 A-2 周期Tでの $S_{v}, S_{a}$ それぞれの低減率と $S_{d}, S_{p v}, S_{p a}$ 共通の低減率の比較 (各周期での 31 波平均)
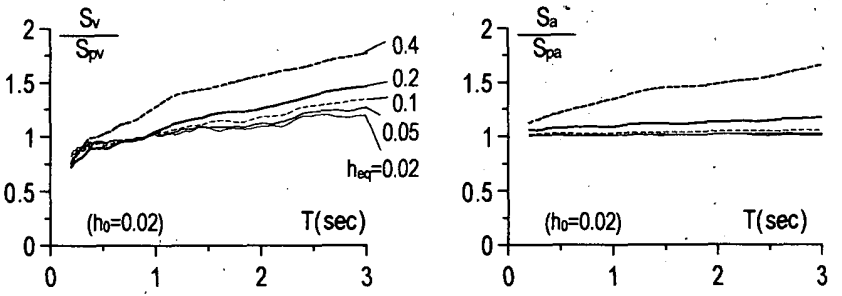

图 A-3 周期 T での $S_{\mathrm{V}} / \mathrm{S}_{\mathrm{pv}}$ および $\mathrm{S}_{\mathrm{a}} / \mathrm{S}_{\mathrm{pa}}$ （各周期での 31 波平均）

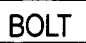

TRIFUNAC \& BRADY
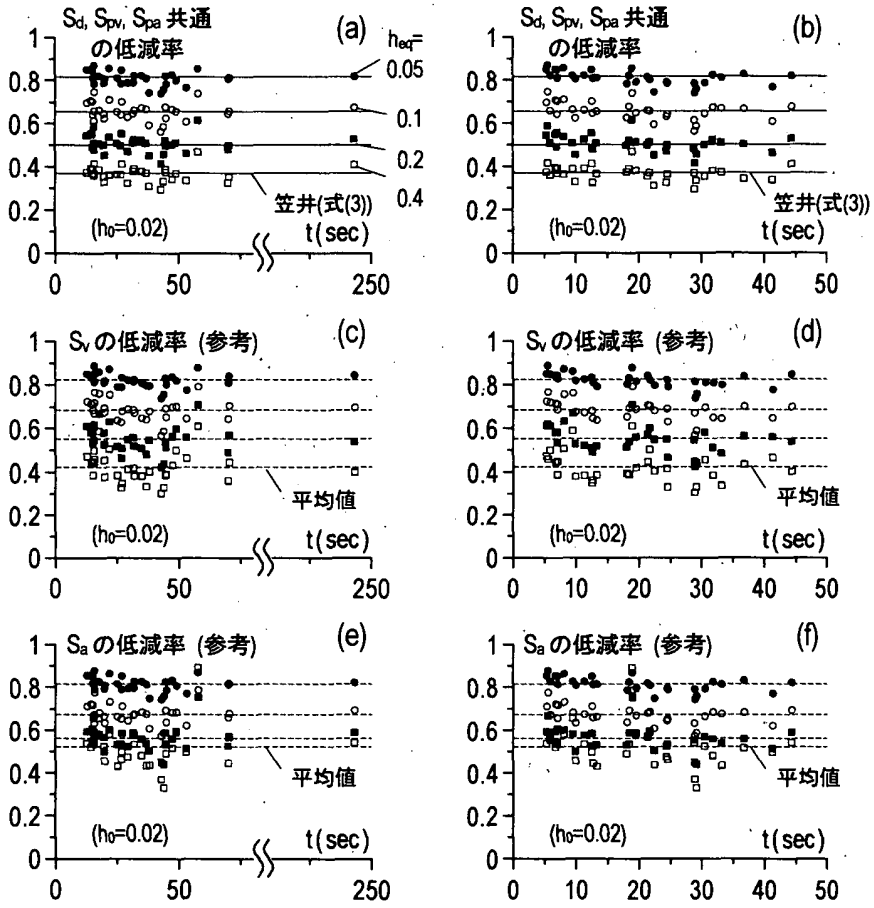

図 A-4 Bolt および Trifunac \& Brady の方法で評価した継続時間 $\mathrm{t}$ と' $\mathrm{S}_{\mathrm{d}} \mathrm{S}_{\mathrm{p}} \mathrm{S}$ S

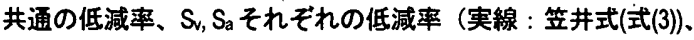
破線 : 平均值、プロット：各地䩲波で周期 $\mathrm{T}=0.2$ ３.0 秒での平均） 
表 2 から、31 実地震波では Bolt の手法では $t=20 \sim 50$ 秒 (平均は 39.7 秒で原波の ほほ $1 / 2$ の長さ)、Trifunac \& Brady では $t=10 \sim 40$ 秒のもの (平均は 19.6 秒で原波の ほほ $1 / 4$ の長さ) が大半を占めることが分かる。

図 A-4 のように $S_{d}\left(S_{p w}, S_{p a}\right.$ と共通) では、両手法から求めた継结時間 $t$ に対する低 減率の相関はほとんと無い。一方 $S_{n} S_{a}$ では、特に高減哀の場合、 $t$ が極端に短いと 低隇率がやや增すが、それ意外では $t$ と低減率の相関は強くない。

(3) 継続時間 $t$ と固有周期 $T$ の比の低減率への影響

上記(1),(2)に基づき、継続時間 $t$ と固有周期 $T$ の比 $t / T$ に対する関連を模討した。 各地震波で $t / T$ データの間陆がそれそれれ異なり、プロットが膨大になるため図示し ないが、 $S_{d}\left(S_{p w}, S_{p}\right.$ と共通) は、隇衰の高低に関わらず $t / T$ の低隇率への影響は小さ く、(1),(2)の傾向を反映した結果となっている。一方で、 $S_{v}, S_{a}$ では $t / T$ が小さいと 低減率が增し、特に高減衰でこれが著しい。

以上、(1) (3)の検討結果から、減衰による $S_{n} S_{a}$ の低減予測には、減衰定数と併 せて他要因も考虑する必要がある。継続時間 $t$ よりも固有周期 $T$ の影響が支配的な ので、これを加味することは勿論だか、長周期・高減衰で精度がばらつくので、パ ルスなどの入力特性も加味する必要があると言える。これと対照的に、 $S_{d}\left(S_{p m} S_{p}\right.$ と共通)の低減率は、周期 0.2 秒 3.0 秒でほほ減哀定数のみで表され(より長周期 の場合は付録 2 参照)、かつ比較的バラツキが少ないため、良好な精度で予測可能 と言える。本論文の等価線形化において、 $S_{v}$ ではなく、 $S_{p v}$ を考慮する理由の一つが ここに在る。

付録2 $S_{d}, S_{p v ｝ S_{p a} \text { I対する低隇率 } D_{h} \text { の拡張式 }$

周期 $0.2 \sim 3.0$ 秒での低減率は、減衰定数のみの関数である $D_{h}$ (式(3))により、精 度良く予測できることを示したが、ここでは広範な周期0～8秒ほどを対象として、 式 (3)を拡張してみる。31 実地震波 (表 2) を考慮して次式を得た。

$$
\begin{array}{lll}
D_{h}=\left[\sqrt{\left(1+25 h_{0}\right) /\left(1+25 h_{e q}\right)}-1\right](5 T)+1 & (0 \leq T \leq 0.2) & \text { (A-1a) } \\
D_{h}=\sqrt{\left(1+25 h_{0}\right) /\left(1+25 h_{e q}\right)} & (0.2 \leq T \leq 2) & \text { (A-1b) } \\
D_{h}=\sqrt{\left(1+25 h_{0}\right) /\left(1+25 h_{e q}\right)}\left[\sqrt{\left(h_{e q} / h_{0}\right)}(T-2) / 40+1\right] & (2 \leq T \leq 8) & (\mathrm{A}-1 \mathrm{c})
\end{array}
$$

図 A-5 が示す如く、式(A-1)は 31 波平均と非常に良く合い、式(3)ほど簡便でな いが、特に長周期構造物の減衰効果の評価に有用と思われる。

ところで本等価線形化手法では、式(3)を等価周期が 3.0 秒以上の場合にも用い ている。この理由は、式(3)が簡便なことと、長周期でも誤差があまり大きくない ことである。ちなみに、本手法に式(3)の代わり式(A-1)を用いたところ、四示しな いか、予測值と解析值の平均か泪 11 より約 $5 \%$ 高い 1.098 となり、標準偏差か殆と 変わらず 0.253 であった。これにより、式(3)を用いた本手法が、長周期の場合にや や少な目の変位予测值を与える (3.5 節) 理由が説明できるが、その簡便性や全般に 良好な精度を考虑すれば、予测法として妥当なものと判断できる。

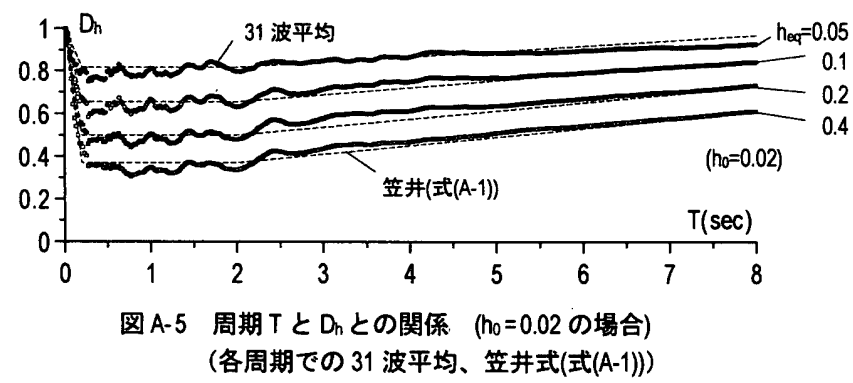

付録了掓似速度応答スペクトル $\mathrm{S}_{\mathrm{pv}}$ の平均化に関する考察

提似速度応答スベクトル $S_{p v}$ を固有周期 $T_{0}$ から等価周期 $T_{e q}$ までの間で平均化す ることにより、無减衰下での平滑化が行われ、塑性化による周期変動を考慮した等 価速度応答スベクトル $\overline{S_{p v}}($ 式(9)) の評価が可能となるか、その効果を検討する。

まず、図 A-6 のように非線形時刻歴解析から半サイクル毎の等価剛性 (破線) と エネルギー吸収 (ハッチング部分) を定義し、それらを用いて半サイクル毎に周期・ 減衰定数を変化させた線形時刻歷解析を行った。例を図 A-7 に示すか、、非線形解析 (a)

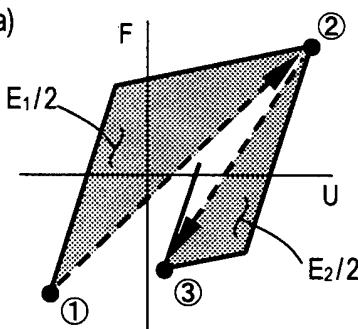

(b)

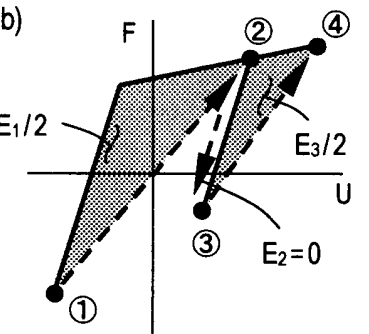

図A-6＼cjkstart半サイクル每における等価剛性とエネルギ一吸収の定练
と等価線形解析がくく致しており、等価周期・減衰を適切に設定することで、非 線形応答を模擬できているのがわかる。

非線形変位

等価線形变位

非楾形復元力

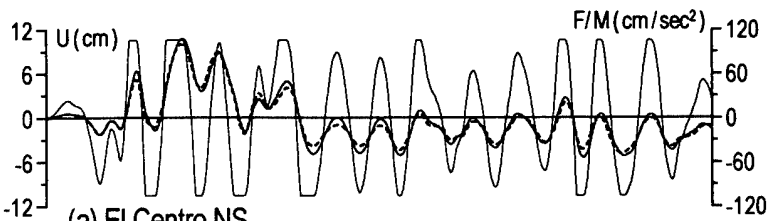

(a) El Centro NS

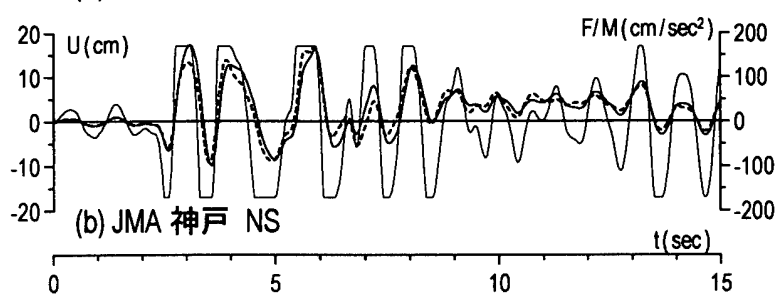

図 A-7 非線形時刻歴解析と等価線形時刻歴解析との比較

（後者は、半サイクル毎に等価周期・隇衰を設定、 $T=1 \mathrm{sec}, p=0, \mu=4$ )

さらに、上の解析にて、等価減衰定数を一定值の初期減衰 $h_{0}$ に変更し、等価周 期のみを半サイクル毎に変化させて時刻歷解析を行った。これを $T_{0}=0.1 \sim 3.0$ 秒の 30 種の弾塑性系に行い、様々な固有周期における最大速度を求め、初期減哀のもと 定義された $\bar{S}_{p v}($ 式(9)) と比へてみる。図A-8 は， $p=0.2, \mu=4$ の場合加ら得た最大 速度と $\bar{S}$ の比較を示すか、後者は前者の傾向をよく捉えていることが分かる。こ のような、初期減衰下で等価周期を用いた解析結果から分かるように、 $S_{p v}$ は塑性 化による周期変動という非線形性およひ地震波のランダム性をよく反映したもの となっており、等価線形化においてその有効性は高いといえる。

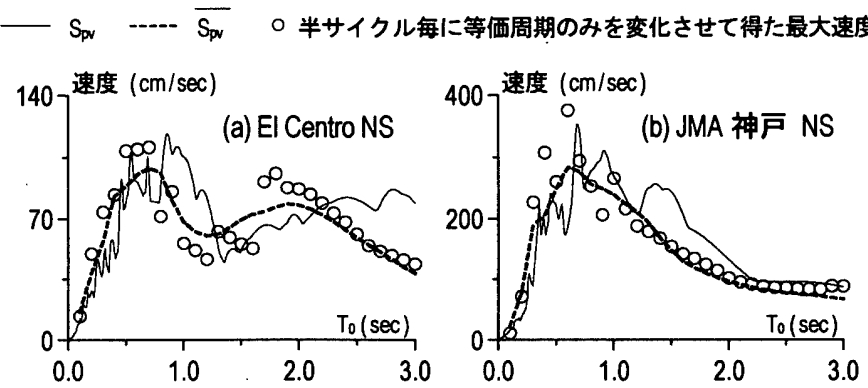

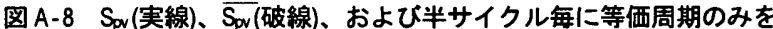
变化させて得た最大速度(O印)の比較（ $\left.h_{0}=0.02, p=0.2, \mu=4\right)$

付録4 柴田によるRC 構造物の等価線形化手法

柴田は、剛性が低下する $\mathrm{RC}$ 骨組の履歷特性に対し、必要耐力と変形の関係を求

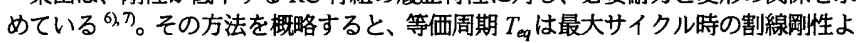
り算出し (式 (8))、等価減衰 $h_{e q}$ は過渡応答を考慮した平均的な減衰として設定し(式 (A-2a))、2\%隇衰のスペクトルの低隇化により応答予㑚を行っている(式(A-2b))。

$$
h_{e q}=\gamma(1-1 / \sqrt{\mu})+h_{0}, D_{h}=8 /\left(6+100 h_{e q}\right)
$$

柴田は $h_{e q}$ を塑性率 $\mu$ のみで評価し、用性低下型の場合 $r=0.2$ と設定しており、島

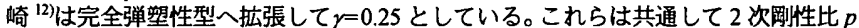
の影響を考慮していない。ここで、 $\gamma=0.25$ として扱うと $h_{\mathrm{qq}}($ 式 $(\mathrm{A}-2 \mathrm{a})$ ) は、本手法(式 (11)) $p=0.25$ の場合と同等の值となる。しかし、本手法の $p<0.25, p>0.25$ の場合の 評価に比へ、 $h_{\text {eq }}$ はそれそれ低め、高めとなっている。また、 $D_{h}($ 式(A-2b)) は既往式 (1) (4)に比へ、任意の $h_{e q}$ において、かなり低い低減率を与える。

また、図 11 (3.5 節)の $p=0,0.2,0.5$ での解析值 (計 8,091 ケース) と比べてみた。 紙幅の都合上図示しないが、予測値と解析值の比は平均 $0.722 、$ 標準偏差 0.295 であ り、前述の傾向のため、 $p$ が大きい場合、より危険側の評価になっている。

なお、柴田の文献 6 では、式(A-2b)か実地霞波応答スベクトルの低減への適用を 意图したものか定かではなく、例として一定の值をとる応答スペクトルの低隇に用 いられているのみである。そこで、そのようなスベクトル性状を示す実地震波を用 いた図 14 (4.4節) の解析值と比較してみた。まず $p=0$ では、加速度応答スペクトル 一定の場合に変位予測值が解析值と良く合う以外 全般に変位を過小評価している。 さらに、 $p=0.2$ や 0.5 では、前述と同粎、式(A-2b)が低めの低隇率を与えるため、 弾塑性応答の傾向を捉えられず、変位を著しく過小評価するケースが多かった。こ れは、柴田による予湘曲線が図 14 の本手法と対比して、降伏力が低い場合で变位 が増加する方向へ折れ曲がる傾向をもたないためである。 